\title{
Complete genome of Phenylobacterium zucineum - a novel facultative intracellular bacterium isolated from human erythroleukemia cell line $\mathrm{K562}$
} Yingfeng $\mathrm{LuO}^{\dagger 1,2,3}$, Xiaoli Xu ${ }^{\dagger 1}$, Zonghui Ding ${ }^{\dagger 1}$, Zhen Liu ${ }^{1}$, Bing Zhang ${ }^{2,3}$, Zhiyu Yan ${ }^{1}$, Jie Sun ${ }^{1}$, Songnian $\mathrm{Hu}^{* 2,3}$ and $\mathrm{Xun} \mathrm{Hu}^{* 1}$

Address: ${ }^{1}$ Cancer Institute (Key Laboratory for Cancer Intervention and Prevention, National Ministry of Education, PR China; Key Laboratory of Molecular Biology in Medical Sciences, Zhejiang Province, PR China), the Second Affiliated Hospital, Zhejiang University School of Medicine, Hangzhou, PR China, ${ }^{2} J a m e s$ D. Watson Institute of Genome Sciences, Zhejiang University, Hangzhou, PR China and ${ }^{3}$ Key Laboratory of Genome Sciences and Information, Beijing Institute of Genomics, Chinese Academy of Sciences, Beijing, PR China

Email: Yingfeng Luo - luoyf@big.ac.cn; Xiaoli Xu - jessie_xuxiaoli@hotmail.com; Zonghui Ding - dingzonghui@yahoo.com.cn; Zhen Liu - liuzhen@cancer.ac.cn; Bing Zhang - zhangbing@big.ac.cn; Zhiyu Yan - yanzhiyu1982@yahoo.com.cn; Jie Sun - sunjie1030@yahoo.com.cn; Songnian Hu* - husn@big.ac.cn; Xun Hu* - huxun@zju.edu.cn

* Corresponding authors †Equal contributors

Published: 13 August 2008

BMC Genomics 2008, 9:386 doi:10.1/86/147|-2164-9-386
Received: 21 August 2007

Accepted: 13 August 2008

This article is available from: http://www.biomedcentral.com/I47/-2164/9/386

(C) 2008 Luo et al; licensee BioMed Central Ltd.

This is an Open Access article distributed under the terms of the Creative Commons Attribution License (http://creativecommons.org/licenses/by/2.0), which permits unrestricted use, distribution, and reproduction in any medium, provided the original work is properly cited.

\begin{abstract}
Background: Phenylobacterium zucineum is a recently identified facultative intracellular species isolated from the human leukemia cell line K562. Unlike the known intracellular pathogens, $P$. zucineum maintains a stable association with its host cell without affecting the growth and morphology of the latter.
\end{abstract}

Results: Here, we report the whole genome sequence of the type strain HLKIT. The genome consists of a circular chromosome (3,996,255 bp) and a circular plasmid (382,976 bp). It encodes $3,86 \mathrm{I}$ putative proteins, 42 tRNAs, and a $16 \mathrm{~S}-23 \mathrm{~S}-5 \mathrm{~S}$ rRNA operon. Comparative genomic analysis revealed that it is phylogenetically closest to Caulobacter crescentus, a model species for cell cycle research. Notably, P. zucineum has a gene that is strikingly similar, both structurally and functionally, to the cell cycle master regulator $\mathrm{CtrA}$ of $C$. crescentus, and most of the genes directly regulated by CtrA in the latter have orthologs in the former.

Conclusion: This work presents the first complete bacterial genome in the genus Phenylobacterium. Comparative genomic analysis indicated that the CtrA regulon is well conserved between $C$. crescentus and $P$. zucineum.

\section{Background}

Phenylobacterium zucineum strain $\mathrm{HLK}^{\mathrm{T}}$ is a facultative intracellular microbe recently identified by us [1]. It is a rod-shaped Gram-negative bacterium $0.3-0.5 \times 0.5-2 \mu \mathrm{m}$ in size. It belongs to the genus Phenylobacterium [2], which presently comprises 5 species, $P$. lituiforme (Fail3T) [3], $P$. falsum (AC49T) [4], P. immobile (ET) [2], P. koreense (Slu01T) [5], and P. zucineum (HLK1 ${ }^{\mathrm{T}}$ [1]. They were isolated from subsurface aquifer, alkaline groundwater, soil, activated sludge from a wastewater treatment plant, and the human leukemia cell line K562, respectively. Except for $P$. zucineum, they are environmental bacteria, and there is no 
evidence that these microbes are associated with eukaryotic cells. The HLK1 ${ }^{\mathrm{T}}$ strain, therefore, represents the only species so far in the genus Phenylobacterium that can infect and survive in human cells. Since most, if not all, of the known microbes that can invade human cells are pathogenic, we proposed that $\mathrm{HLK} 1^{\mathrm{T}}$ may have pathogenic relevance to humans [1]. Unlike the known intracellular pathogens that undergo a cycle involving invasion, overgrowth, and disruption of the host cells, and repeating the cycle by invading new cells, HLK1 ${ }^{\mathrm{T}}$ is able to establish a stable parasitic association with its host, i.e., the strain does not overgrow intracellularly to kill the host, and the host cells carry them to their progeny. One cell line (SW480) infected with $P$. zucineum has been stably maintained for nearly three years in our lab (data not shown).

In this report, we present the complete genome sequence of P. zucineum.

\section{Results}

\section{Genome anatomy}

The genome is composed of a circular chromosome $(3,996,255 \mathrm{bp})$ and a circular plasmid $(382,976 \mathrm{bp})$ (Figure 1; Table 1). The $\mathrm{G}+\mathrm{C}$ contents of chromosome and plasmid are $71.35 \%$ and $68.5 \%$, respectively. There are 3,861 putative protein-coding genes $(3,534$ in the chromosome and 327 in the plasmid), of which 3,180 have significant matches in the non-redundant protein database. Of the matches, 585 are conserved hypothetical proteins and 2,595 are proteins with known or predicted functions. Forty-two tRNA genes and one 16S-23S-5S rRNA operon were identified in the chromosome.

There are 7 families of protein-coding repetitive sequences and a family of noncoding repeats in the genome (Table 2). Notably, identical copies of repeats 02-04 were found in both the chromosome and the plasmid, suggesting their potential involvement in homologous recombination.

On the basis of COG (Cluster of Orthologous Groups) classification, the chromosome is enriched in genes for basic metabolism, such as categories E (amino acid transport and metabolism) and I (lipid transport and metabolism), accounting for $8.29 \%$ and $6.09 \%$ of the total genes in the chromosome, respectively. On the other hand, the plasmid is enriched for genes in categories $\mathrm{O}$ (posttranslational modification, protein turnover, chaperones) and $\mathrm{T}$

Table I: Genome summary of $P$. zucineum Strain $H L K I^{\top}$

\begin{tabular}{|c|c|c|c|}
\hline Genomic Element & & Chromosome & plasmid \\
\hline Length (bp) & & $3,996,255$ & 382,976 \\
\hline GC content (\%) & & 71.35 & 68.54 \\
\hline \multirow[t]{5}{*}{ Proteins } & & 3,534 & 327 \\
\hline & Coding region of genome $(\%)$ & $88.85 \%$ & $81.94 \%$ \\
\hline & Proteins with known or predicted function & $2,394(67.75 \%)$ & $201(61.47 \%)$ \\
\hline & Conserved hypothetical proteins & $560(15.84 \%)$ & $25(7.65 \%)$ \\
\hline & Hypothetical proteins & $580(16.41 \%)$ & $101(30.88 \%)$ \\
\hline rRNA operon & & 1 & 0 \\
\hline tRNAs & & 42 & 0 \\
\hline Proteins in each & [J] Translation, ribosomal structure and biogenesis & $185(5.24 \%)$ & $3(1.21 \%)$ \\
\hline \multirow{19}{*}{ COG category } & {$[\mathrm{K}]$ Transcription } & $210(5.94 \%)$ & 22 (8.91\%) \\
\hline & [L] Replication, recombination and repair & $139(3.93 \%)$ & $23(9.31 \%)$ \\
\hline & [D] Cell cycle control, cell division, chromosome partitioning & $27(0.76 \%)$ & 0 \\
\hline & [V] Defense mechanisms & 51 ( $1.44 \%)$ & $3(1.21 \%)$ \\
\hline & [T] Signal transduction mechanisms & $166(4.7 \%)$ & $24(9.72 \%)$ \\
\hline & [M] Cell wall/membrane/envelope biogenesis & $195(5.52 \%)$ & $15(6.07 \%)$ \\
\hline & [N] Cell motility & $62(1.75 \%)$ & $4(1.62 \%)$ \\
\hline & [U] Intracellular trafficking, secretion, and vesicular transport & $96(2.72 \%)$ & $13(5.26 \%)$ \\
\hline & [O] Posttranslational modification, protein turnover, chaperones & $151(4.27 \%)$ & $32(12.96 \%)$ \\
\hline & [C] Energy production and conversion & $188(5.32 \%)$ & $16(6.48 \%)$ \\
\hline & [G] Carbohydrate transport and metabolism & $161(4.56 \%)$ & $15(6.07 \%)$ \\
\hline & [E] Amino acid transport and metabolism & $293(8.29 \%)$ & $5(2.02 \%)$ \\
\hline & [F] Nucleotide transport and metabolism & $58(1.64 \%)$ & $3(1.21 \%)$ \\
\hline & {$[\mathrm{H}]$ Coenzyme transport and metabolism } & $116(3.28 \%)$ & $3(1.21 \%)$ \\
\hline & [1] Lipid transport and metabolism & $215(6.09 \%)$ & $12(4.86 \%)$ \\
\hline & [P] Inorganic ion transport and metabolism & $223(6.31 \%)$ & $24(9.72 \%)$ \\
\hline & [Q] Secondary metabolites biosynthesis, transport and catabolism & $152(4.3 \%)$ & $9(3.64 \%)$ \\
\hline & [R] General function prediction only & $444(12.57 \%)$ & $28(11.34 \%)$ \\
\hline & [S] Function unknown & $307(8.69 \%)$ & $20(8.10 \%)$ \\
\hline
\end{tabular}




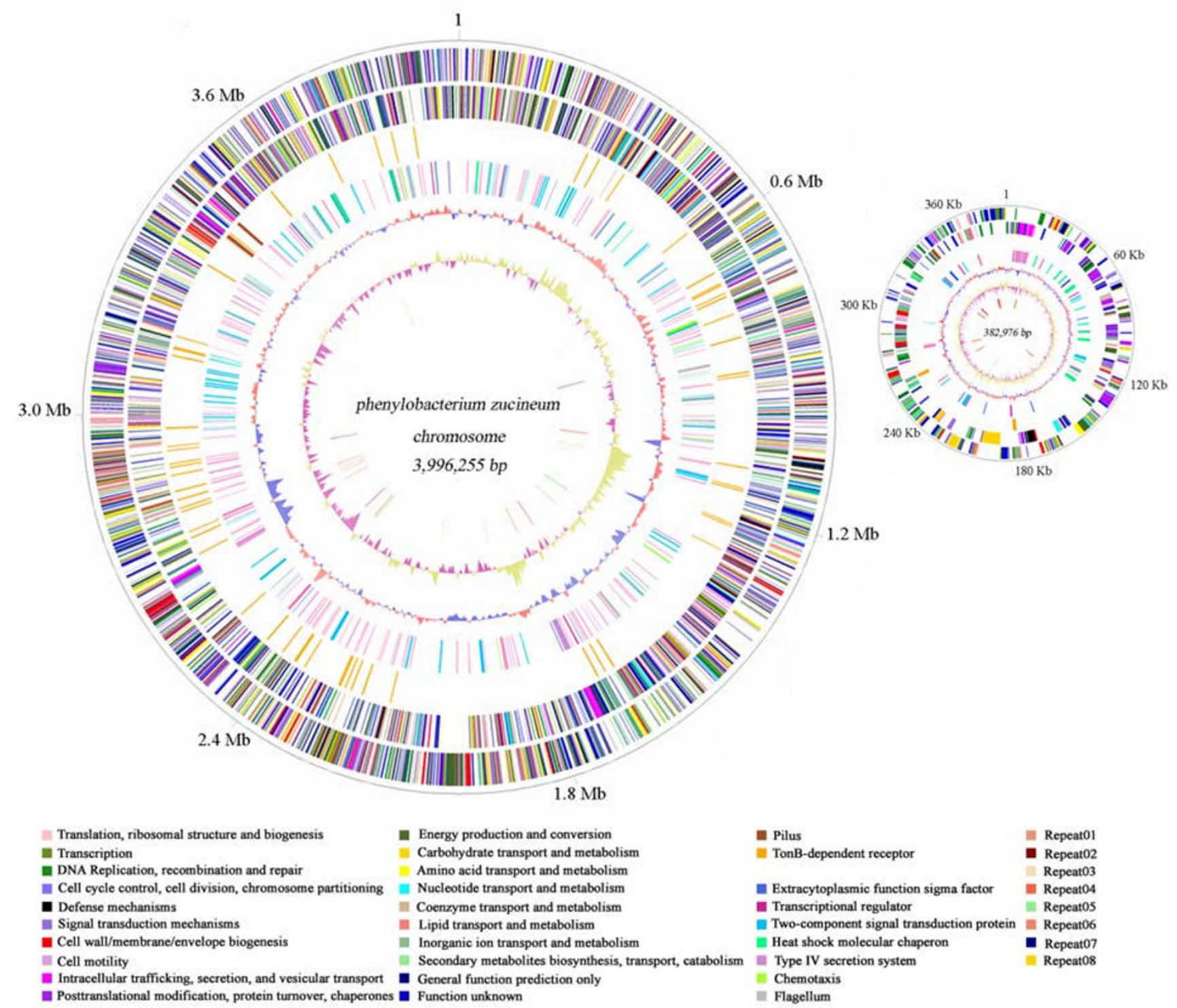

Figure I

Circular representation of the $P$. zucineum strain HLKIT chromosome and plasmid (smaller circle). Circles indicate (from the outside): (I) Physical map scaled in megabases from base I, the start of the putative replication origin. (2) Coding sequences transcribed in the clockwise direction are color-coded according to COG functional category. (3) Coding sequences transcribed in the counterclockwise direction are color-coded according to COG functional category. (4) Proteins involved in establishment of intracellular niche are TonB-dependent receptors (orange) and pilus genes (sienna). (5) Functional elements responsible for environmental transition are extracytoplasmic function sigma factors (royal blue), transcriptional regulators (violet red), two-component signal transduction proteins (deep sky blue), heat shock molecular chaperons (spring green), type IV secretion systems (plum), chemotaxis systems (green yellow) and flagellum proteins (gray). (6) G + C percent content (I0-kb window and I-kb incremental shift for chromosome; 300 bp window and I50 bp for incremental shift for plas$\mathrm{mid}$ ); values larger than average (7I.35\% in chromosome and $68.5 \%$ in plasmid) are in red and smaller in medium blue. (7) GC skew (I0-kb window and I-kb incremental shift for chromosome; $300 \mathrm{bp}$ window and I50 bp for incremental shift for plasmid); values greater than zero are in gold and smaller in purple. (8) Repeat families, repeats 0I-08 are in dark salmon, dark red, wheat, tomato, light green, salmon, dark blue and gold, respectively. 
Table 2: Repetitive elements in the $P$. zucineum genome

\begin{tabular}{|c|c|c|c|c|c|c|c|c|}
\hline \multirow[t]{2}{*}{ Repeat ID } & \multirow[t]{2}{*}{ Length bp } & \multirow[t]{2}{*}{ DR' } & \multicolumn{2}{|c|}{ Number of copies } & \multicolumn{2}{|c|}{ Position of insertion } & \multirow[t]{2}{*}{ Identity (\%) } & \multirow[t]{2}{*}{ Coding information } \\
\hline & & & Complete $^{2}$ & Partial & Chromosome & Plasmid & & \\
\hline Repeat0 ${ }^{3}$ & 2,587 & 7 & 3 & I & 0 & 4 & $>99$ & Transposase \\
\hline Repeat024 & 1,262 & 3 & 3 & I & 2 & 2 & 100 & Transposase \\
\hline Repeat035 & 1,392 & NA & 4 & 2 & 4 & 2 & 100 & Transposase \\
\hline Repeat046 & 1,257 & NA & 10 & 0 & 7 & 3 & 100 & Transposase \\
\hline Repeat05 & $\mathrm{I}, 554$ & NA & 2 & 0 & 2 & 0 & $>98$ & Hypothetical protein \\
\hline Repeat06 & 1,136 & NA & 2 & 0 & 2 & 0 & $>90$ & Isovaleryl-CoA dehydrogenase \\
\hline Repeat07 & 1,077 & NA & 2 & 0 & 2 & 0 & $>98$ & 2-nitropropane dioxygenase \\
\hline Repeat08 & $\approx 130$ & NA & 13 & 0 & 13 & 0 & $>90$ & Noncoding repeats \\
\hline
\end{tabular}

\footnotetext{
ISize in base pairs of the consensus and the direct repeat (DR) generated by insertion into the genome target site.

${ }^{2} \mathrm{~A}$ copy is complete if the length of the repeat is $\geq 90 \%$ of the consensus, otherwise, the copy is partial.

${ }^{3}$ One complete copy which harbors a 7 bp direct repeat (TCCTAAC) that disrupts the VirD4.

${ }^{4}$ The partial copy is located in the plasmid.

5Two partial copies are located in the chromosome, of which a "partial" copy with full length is inserted by a copy of repeat04.

${ }^{6}$ repeats $01-04$ are IS elements
}

(signal transduction mechanisms), constituting 12.96\% and $9.72 \%$ of the total genes in the plasmid, respectively.

As to genes in the plasmid that cope with environmental stimuli, about half of the genes in category $\mathrm{O}$ are molecular chaperones (17/32), including 2 dnaJ-like molecular chaperones, 2 clusters of $d n a K$ and its co-chaperonin grpE (PHZ_p0053-0054 and PHZ_p0121-122), a cluster of groEL and its co-chaperonin groES (PHZ_p0095-0096), and 9 heat shock proteins Hsp20. Of 23 genes in category T, there is one cluster (FixLJ, PHZ_p0187-0188), which is essential for the growth of $C$. crescentus under hypoxic conditions [6].

\section{General metabolism}

The enzyme sets of glycolysis and the Entner-Doudoroff pathway are complete in the genome. All genes comprising the pentose phosphate pathway except gluconate kinase were identified, consistent with our previous experimental result that the strain cannot utilize gluconate [1]. The genome lacks two enzymes $(k d h$, alpha ketoglutarate dehydrogenase and $k g d$, alpha ketoglutarate decarboxylase), making the oxidative and reductive branches of the tricarboxylic acid cycle operate separately. The genome has all the genes for the synthesis of fatty acids, 20 amino acids, and corresponding tRNAs. Although full sets of genes for the biosynthesis of purine and pyrimidine were identified, enzymes for the salvage pathways of purine (apt, adenine phosphoribosyltransferase; ade, adenine deaminase) and pyrimidine ( $c d d$, cytidine deaminase; $\operatorname{codA}$, cytosine deaminase; $t d k$, thymidine kinase; deoA, thymidine phosphorylase; $u p p$, uracil phosphoribosyltransferase; $u d k$, uridine kinase; and $u d p$, uridine phosphorylase) were absent. The plasmid encodes some metabolic enzymes, such as those participating in glycolysis, the pentose phosphate pathway, and the citric acid cycle. However, it is worth noting that the plasmid has a gene (6-phosphogluconate dehydrogenase) that is the only copy in the genome (PHZ_p0183).

Like most other species in the genus Phenylobacterium, the strain is able to use L-phenylalanine as a sole carbon source under aerobic conditions [1]. A recent study revealed that phenylalanine can be completely degraded through the homogentisate pathway in Pseudomonas putida U [7]. P. zucineum may use the same strategy to utilize phenylalanine, because all the enzymes for the conversion of phenylalanine through intermediate homogentisate to the final products fumarate and acetoacetate are present in the chromosome (Table 3).

\section{Functional elements responding to environmental transition}

$\mathrm{HLK}^{\mathrm{T}}$ is able to survive intracellularly and extracellularly. Consistently, the genome contains the fundamental elements to support the life cycle in different environments. The genome contains abundant two-component signal transduction proteins, transcriptional regulators, and heat shock response proteins, enabling the strain to respond to extra- and intra-cellular stimuli at transcriptional and post-translational levels. Among the total of 102 twocomponent signal transduction proteins (91 in the chromosome and 11 in the plasmid), there are 36 histidine kinases, 48 response regulators, and 18 hybrid proteins fused with histidine kinase and response regulator. Sixteen pairs of histidine kinase and response regulator (1 in the plasmid) are adjacently aligned and may act as functional operons. These tightly linked modules make twocomponent signal transduction systems respond to environmental changes efficiently. The genome encodes 170 transcriptional regulators (16 in the plasmid) (Table 4). Notably, we annotated the proteins of 93 bacteria (see 
Table 3: Phenylalanine-degrading enzymes in the $P$. zucineum genome

\begin{tabular}{|c|c|c|c|c|c|c|c|c|}
\hline \multirow[t]{2}{*}{ Gene } & \multirow[t]{2}{*}{ P. zucineum Locus } & \multicolumn{2}{|c|}{ Length (bp) } & \multicolumn{2}{|c|}{ Alignment coverage (\%) } & \multirow[t]{2}{*}{ Score } & \multirow[t]{2}{*}{ Amino acid Identity (\%) } & \multirow[t]{2}{*}{ Gene name } \\
\hline & & P. putida & P. zucineum & P. putida & P. zucineum & & & \\
\hline phhA & PHZ_cl409 & 262 & 308 & 83.59 & 71.75 & 219 & 48.65 & phenylalanine-4-hydroxylase \\
\hline phhB & PHZ_c0077 & 118 & 97 & 79.66 & 93.81 & 38.5 & 26.32 & carbinolamine dehydratase \\
\hline tryB & PHZ_cl644 & 398 & 406 & 60.05 & 57.39 & 33.9 & 21.86 & tyrosine aminotransferase \\
\hline hpd & PHZ_c2833 & 358 & 374 & 98.32 & 93.58 & 398 & 57.98 & $\begin{array}{l}\text { 4-hydroxyphenylpyruvate } \\
\text { dioxygenase }\end{array}$ \\
\hline$h m g A$ & PHZ_c283I & 433 & 377 & 60.28 & 67.64 & 53.5 & 22.3 & homogentisate 1,2-dioxygenase \\
\hline$h m g B$ & PHZ_c0313 & 430 & 226 & 9.77 & 18.14 & 27.7 & 39.53 & fumarylacetoacetate hydrolase \\
\hline hmgC & PHZ_c0314 & 210 & 212 & 98.1 & 98.11 & 213 & 51.67 & maleylacetoacetate isomerase \\
\hline
\end{tabular}

methods - comparative genomics) with the same annotation criteria used for P. zucineum and found that the fraction of two-component signal transduction proteins and transcriptional regulators was positively correlated with the capacity for environmental adaptation (Figure 2). The genome contains 17 extracytoplasmic function (ECF) sigma factors (3 in the plasmid) (Table 5). ECFs are suggested to play a role in environmental adaptation for Pseudomonas putida KT2440, whose genome contains 19 ECFs [8]. P. zucineum has 3 heat shock sigma factors $r p o H$ (2 in the plasmid) and 33 heat shock molecular chaperons (17 in the plasmid) (Table 6), which can cope with a variety of stresses, including cellular energy depletion, extreme concentrations of heavy metals, and various toxic substances. [9].

The genes for cell motility include 3 chemotaxis operons, 7 MCP (methyl-accepting chemotaxis) genes, 15 other

Table 4: Transcriptional regulators in the $P$. zucineum genome genes related to chemotaxis (Table 7), and 43 genes for the biogenesis of the flagellum (Table 8).

The genome contains sec-dependent, sec-independent, typical type II (Table 9) and IV secretion systems (Table $10)$, which are known to play important roles in adapting to diverse conditions $[10,11]$.

To better understand the roles of proteins responsible for environmental transition, we computed the distributions of those proteins in 5 representative alphaproteobacteria with typical habitats (see methods - comparative genomics). Like other multiple bacteria and facultative bacteria, which can survive in multiple niches, $P$. zucineum encodes a higher fraction of ECFs, transcriptional regulators and two-component signal transduction proteins than obligate bacteria (Table 9). Notably, P. zucineum has the largest number of heat shock related proteins (Table 6), in comparison to the 5 representative alphaproteobacteria

\begin{tabular}{|c|c|c|c|c|}
\hline Family name & Action type & Chromosome & Plasmid & Proposed roles \\
\hline AsnC family & Activator/repressor & 8 & 0 & Amino acid biosynthesis \\
\hline AraC family & Activator & 10 & I & Carbon metabolism, stress response and pathogenesis \\
\hline ArsR family & Repressor & 8 & 0 & Metal resistance \\
\hline Blal family & Repressor & 2 & 0 & Penicillin resistance \\
\hline Cold shock family & Activator & 6 & 0 & Low-temperature resistance \\
\hline Cro/Cl family & Repressor & 9 & 2 & Unknown ${ }^{2}$ \\
\hline Crp/Fnr family & Activator/repressor & 7 & 2 & Global responses, catabolite repression and anaerobiosis \\
\hline GntR family & Repressor & 7 & 0 & General metabolism \\
\hline Lacl family & Repressor & 4 & 0 & Carbon source utilization \\
\hline LuxR family & Activator & 5 & I & Quorum sensing, biosynthesis and metabolism, etc. \\
\hline LysR family & Activator/repressor & 15 & 1 & Carbon and nitrogen metabolism \\
\hline MarR family & Activator/repressor & 6 & 0 & Multiple antibiotic resistance \\
\hline MerR family & Repressor & 9 & 2 & Resistance and detoxification \\
\hline TetR family & Repressor & 22 & 0 & Biosynthesis of antibiotics, efflux pumps, osmotic stress, etc. \\
\hline XRE family & Repressor & 2 & 2 & Unknown (initial function is lysogeny maintenance) \\
\hline Other types ${ }^{2}$ & - & 34 & 5 & - \\
\hline Total & - & 154 & 16 & - \\
\hline
\end{tabular}

Initial function is related to controlling the expression of phage gene

$2 " O t h e r$ types" include the transcriptional regulators with only one member in the $P$. zucineum genome or transcriptional regulators that could not be classified into any known family. 
Table 5: Extracytoplasmic function (ECF) sigma factors in the $P$. zucineum genome

\begin{tabular}{|c|c|c|c|c|}
\hline \multirow[t]{2}{*}{ Locus } & \multicolumn{3}{|c|}{ Location of proteins } & \multirow[t]{2}{*}{ COG category } \\
\hline & Genomic element & 5 '-end & 3'-end & \\
\hline PHZ_P0I5I & Plasmid & 171,032 & 170,316 & COGI595I \\
\hline PHZ_P0I74 & Plasmid & 208,703 & 208,053 & COGI595 \\
\hline PHZ_P0192 & Plasmid & 229,133 & 228,516 & COGI595 \\
\hline PHZ_c0249 & Chromosome & 249,840 & 250,553 & COGI595 \\
\hline PHZ_c030I & Chromosome & 296,299 & 295,706 & COGI595 \\
\hline PHZ_cl475 & Chromosome & $1,676,920$ & $1,677,492$ & COGI595 \\
\hline PHZ_cl529 & Chromosome & $\mathrm{I}, 730,783$ & $\mathrm{I}, 73 \mathrm{I}, 403$ & COGI595 \\
\hline PHZ_cl53I & Chromosome & $1,732,219$ & $\mathrm{I}, 732,800$ & COGI595 \\
\hline PHZ_cl907 & Chromosome & $2,|34,97|$ & $2,135,507$ & COGI595 \\
\hline PHZ_c2|7I & Chromosome & $2,447,581$ & $2,448,396$ & COGI595 \\
\hline PHZ_c2233 & Chromosome & $2,526,836$ & $2,527,369$ & COGI595 \\
\hline PHZ_c2394 & Chromosome & $2,724,759$ & $2,725,307$ & COGI595 \\
\hline $\mathrm{PHZ} \_\mathrm{c} 2577$ & Chromosome & $2,965,250$ & $2,964,390$ & COGI595 \\
\hline PHZ_c2585 & Chromosome & $2,970,368$ & $2,969,811$ & COGI595 \\
\hline PHZ_c2684 & Chromosome & $3,077,272$ & $3,076,727$ & COGI595 \\
\hline PHZ_c0569 & Chromosome & $605,44 I$ & 604,233 & COG $4941^{2}$ \\
\hline PHZ_c3I54 & Chromosome & $3,582,010$ & $3,583,269$ & COG494I \\
\hline
\end{tabular}

ICOGI595, DNA-directed RNA polymerase specialized sigma subunit, sigma24 homolog;

${ }^{2}$ COG 494I, predicted RNA polymerase sigma factor containing a TPR repeat domain

and 93 bacteria (data not shown). Among the plasmidencoded heat shock related proteins are $2 \mathrm{RpoH}$ (PHZ_p0049 and PHZ_p0288) and 2 DnaK-GrpE clusters (PHZ_p0053-0054 and PHZ_p0121-0122). Further phylogenetic analysis suggested that the plasmid-encoded DnaK-GrpE clusters may have undergone a genus-specific gene duplication event (Figure 3C \&3D).

\section{Adaptation to an intracellular life cycle}

To survive intracellularly, $P$. zucineum must succeed in adhering to and subsequently invading the host cell [12], defending against a hostile intracellular environment [13$16]$, and capturing iron at very low concentration [17].

It is well known that the pilus takes part in adhering to and invading a host cell [12]. We identified one pili biosynthesis gene (pilA) and 2 operons for pili biosynthesis (Table 11).

The genes involved in defense against oxidative stress include superoxide dismutase (PHZ_c0927, PHZ_c1092), catalase (PHZ_c2899), peroxiredoxin (PHZ_c1548), hydroperoxide reductase $(a h p F$, alkyl hydroperoxide

Table 6: Distribution of heat shock related proteins in P. zucineum and representative alphaproteobacteria with different living habitats

\begin{tabular}{|c|c|c|c|c|c|c|c|}
\hline \multirow[t]{2}{*}{ ContentISpecies } & \multirow[t]{2}{*}{ S. meliloti } & \multirow[t]{2}{*}{ B. suis } & \multirow[t]{2}{*}{ C. crescentus } & \multicolumn{2}{|c|}{ P. zucineum } & \multirow[t]{2}{*}{ R. conorii } & \multirow[t]{2}{*}{ G. oxydans } \\
\hline & & & & Chromosome & Plasmid & & \\
\hline rpoH, heat shock sigma factorl & 2 & 2 & I & 1 & 2 & 1 & 1 \\
\hline dnaK, molecular chaperone ${ }^{2}(\mathrm{Hsp} 70)$ & I & I & $\mathrm{I}$ & I & 2 & $\mathrm{I}$ & I \\
\hline grpE, molecular chaperone (co-chaperonin of Hsp70) & I & I & $\mathrm{I}$ & I & 2 & $\mathrm{I}$ & $\mathrm{I}$ \\
\hline dnaK-like molecular chaperone & $\mathrm{I}$ & I & I & I & 0 & $\mathrm{I}$ & $\mathrm{I}$ \\
\hline dnaJ, molecular chaperone & 1 & 1 & $\mathrm{I}$ & 1 & 0 & 1 & 1 \\
\hline dnaJ-like molecular chaperone & 4 & 3 & 3 & 6 & 2 & I & 3 \\
\hline groEL, molecular chaperone (hsp60) & 5 & I & I & 1 & I & I & I \\
\hline groES, molecular chaperone (Hsp I0, co-chaperonin of Hsp60) & 3 & I & I & $\mathrm{I}$ & I & I & I \\
\hline molecular chaperone Hsp20 & 5 & 2 & 2 & 3 & 9 & 0 & 3 \\
\hline molecular chaperone Hsp33 & 1 & 1 & I & 1 & 0 & 0 & I \\
\hline
\end{tabular}

IrpoH may be responsible for the expression of some or all heat shock proteins

${ }^{2}$ The function of molecular chaperones is to protect unfolded proteins induced by stress factors through renaturation or degradation in cooperation with protease. 

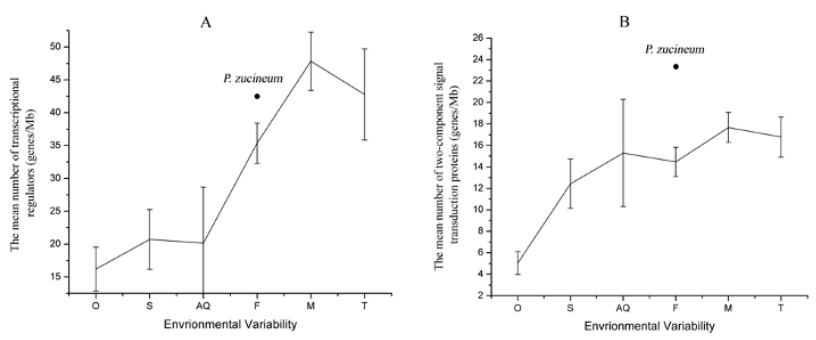

Figure 2

Comparative analysis of transcriptional regulators and two-component signal transduction proteins in 6 groups of bacteria classified according to their habitats. (A): The mean number of transcriptional regulators in each megabase pair of the genomes. (B): The mean number of two-component signal transduction proteins in each megabase pair of the genomes. The fraction of transcriptional regulators and two-component signal transduction proteins (solid black circle) of $P$. zucineum were $4 \mathrm{I} .56$ genes/Mb and 23.30 genes/Mb, respectively. Error bars represent standard errors. O: Obligate (26 species), S: Specialized (5 species), AQ: Aquatic (4 species), F: Facultative (28 species), M: Multiple (27 species), T: Terrestrial (3 species).

reductase, subunit f, PHZ_c2725, ahpC, alkyl hydroperoxide reductase, subunit $\left.\mathrm{c}, \mathrm{PHZ} \_2724\right)$, and the glutathione redox cycle system (glutathione reductase [PHZ_c1740, PHZ_c1981], glutathione synthetase [PHZ_c3479], and $\gamma$-glutamylcysteine synthetase [PHZ_c0446, PHZ_c0523]).

Since intracellular free $\mathrm{Fe}$ is not sufficient to support the life of bacteria, to survive intracellularly, they must use protein-bound iron, such as heme and transferrin, via transporters and/or the siderophore system. The P. zucineum genome has one $\mathrm{ABC}$ type siderophore transporter system (PHZ_c1893-1895), one ABC type heme transporter system (PHZ_c0136, PHZ_c0139, PHZ_c0140), and 60 TonB-dependent receptors which may uptake the iron-siderophore complex (Table 12).

\section{Comparative genomics between $\mathrm{P}$. zucineum and $\mathrm{C}$. crescentus}

Comparative genomic analysis demonstrated that $P$. zucineum is phylogenetically the closest to C. crescentus [18] (Figure 4), consistent with the phylogenetic analysis based on 16S RNA gene sequences (Figure 5).

Though the genome size and protein number of $P$. zucineum (4.37 Mb, 3,861 proteins) are similar to those of $C$. crescentus (4.01 Mb, 3,767 proteins), no large-scale synteny was found between the genomes. The largest synteny region is only about $30 \mathrm{~kb}$ that encodes 24 proteins. The conservation region with the largest number of proteins is the operon encoding 27 ribosomal proteins. In addition, the species share only $57.8 \%(2,231 / 3,861)$ of orthologous proteins. Categories $\mathrm{J}$ (translation, ribosomal structure and biogenesis), F (nucleotide transport and metabolism), and $\mathrm{L}$ (replication, recombination and repair) are the top 3 conservative COG categories between the species, sharing $88.01 \%, 81.67 \%$, and $80.65 \%$ of the orthologs, respectively.

\section{Comparison of cell cycle genes between P. zucineum and C. crescentus}

Since $P$. zucineum is phylogenetically closest to C. crescentus, and since the latter is a model organism for studies of the prokaryotic cell cycle $[19,20]$, we compared the genes regulating the cell cycle between these species.

The cell cycle of $C$. crescentus is controlled to a large extent by the master regulator $\mathrm{CtrA}$, which controls the transcription of 95 genes involved in the cycle $[19,20]$. On the other hand, $c t r A$ is regulated at the levels of transcription, phosphorylation, and proteolytic degradation by its target genes, e.g., DNA methyltransferase (CcrM) regulates the transcription of $c t r A$, histidine kinases (CckA, PleC, DivJ, DivL) regulate its activity, and ClpXP degrades it. These regulatory 'loops' enable CtrA to precisely control the progression of the cell cycle.

P. zucineum has most of the orthologs mentioned above (Table 13). Among the 95 CtrA-regulated genes in C. crescentus, 75 have orthologs in the $P$. zucineum genome (Additional file 1). The fraction of CtrA-regulated genes with orthologs in P. zucineum $(76.9 \%, 73 / 95)$ is significantly greater than the mean level of the whole genome $(57.8 \%, 2,231 / 3,861)$, indicating that the CtrA regulatory system is highly conserved. Genes participating in regulating central events of the cell cycle, such as CcrM (CC0378), Clp protease (CC1963) and 14 regulatory proteins, except for one response regulator (CC3286), are present in the $P$. zucineum genome. The genes without counterparts in $P$. zucineum are mostly for functionally unknown proteins.

Notably, the sequence of CtrA is strikingly similar between P. zucineum and C. crescentus, with $93.07 \%$ identity of amino acid sequence and $89.88 \%$ identity of nucleotide sequence. In addition, they share identical promoters (p1 and p2) [21] and the motif (GAnTC) recognized by DNA methyltransferase (CcrM) (Figure 6) [22], suggesting that they probably share a similar regulatory loop of CtrA.

Consistent with the results from in silico sequence analysis, the CtrA of P. zucineum can restore the growth of temperature-sensitive strain LC2195 (a CtrA mutant) of $C$. crescentus [23] at $37^{\circ} \mathrm{C}$, indicating that the CtrA of P. zuci- 
Table 7: Chemotaxis proteins in the $P$. zucineum genome

\begin{tabular}{|c|c|c|c|c|c|c|}
\hline Locus $P$. zucineum & 5'-end & 3'-end & Name & $\begin{array}{c}\text { Orthologs } C \text {. } \\
\text { crescentus }\end{array}$ & Operon & Best BLAST match \\
\hline PHZ_c0690 & 753,270 & 753,812 & chemotaxis protein $\mathrm{CheW}$ & - & I & M. magneticum AMB-I \\
\hline $\mathrm{PHZ} \_0691$ & 753,812 & 755,218 & chemotaxis protein methyltransferase CheR & - & 1 & M. magnetotacticum MS-I \\
\hline $\mathrm{PHZ} \_0692$ & 755,240 & 755,836 & chemotaxis signal transduction protein & - & I & Rhodospirillum centenum \\
\hline PHZ_c0693 & 755,836 & 757,488 & methyl-accepting chemotaxis protein & - & 1 & M. magneticum AMB-I \\
\hline PHZ_c0694 & 757,501 & 759,642 & chemotaxis histidine kinase $\mathrm{CheA}$ & - & 1 & M. magnetotacticum MS-I \\
\hline PHZ_c0695 & 759,642 & 760,709 & chemotaxis response regulator $\mathrm{CheB}$ & - & I & Rhodospirillum centenum \\
\hline $\mathrm{PHZ} \_\mathrm{c} 3230$ & $3,661,514$ & $3,661,050$ & CheE protein & - & 2 & C. crescentus $C B / 5$ \\
\hline PHZ_c323I & $3,662,099$ & $3,661,527$ & chemotaxis protein CheYIII & CC0440 & 2 & C. crescentus $C B / 5$ \\
\hline $\mathrm{PHZ} \_\mathrm{c} 3233$ & $3,662,860$ & $3,662,477$ & chemotaxis protein CheYII & CC0591 & 2 & R. palustris CGA009 \\
\hline PHZ_c3234 & $3,663,186$ & $3,666,188$ & chemotaxis histidine kinase CheA & CC0594 & 2 & Azospirillum brasilense \\
\hline PHZ_c3235 & $3,666,188$ & $3,666,733$ & chemotaxis protein $\mathrm{CheW}$ & CC0595 & 2 & Rhodospirillum centenum \\
\hline PHZ_c3236 & $3,666,786$ & $3,669,191$ & methyl-accepting chemotaxis protein $\mathrm{McpH}$ & CC3349 & 2 & R. palustris CGA009 \\
\hline PHZ_c3237 & $3,670,166$ & $3,669,336$ & chemotaxis protein methyltransferase CheR & $\mathrm{CC} 0598$ & 2 & R. palustris $\mathrm{HaA2}$ \\
\hline PHZ_c3238 & $3,671,242$ & $3,670,166$ & chemotaxis response regulator $\mathrm{CheB}$ & CC0597 & 2 & M. magneticum AMB-I \\
\hline PHZ_c337I & $3,820,121$ & $3,819,669$ & CheE protein & CC044I & 3 & C. crescentus CB/5 \\
\hline PHZ_c3372 & $3,820,729$ & $3,820,124$ & chemotaxis protein CheYIII & - & 3 & C. crescentus $C B / 5$ \\
\hline PHZ_c3373 & $3,821,034$ & $3,820,729$ & CheU protein & CC0439 & 3 & C. crescentus $C B / 5$ \\
\hline PHZ_c3374 & $3,821,651$ & $3,821,082$ & chemotaxis protein CheD & CC0438 & 3 & C. crescentus $C B / 5$ \\
\hline PHZ_c3375 & $3,822,037$ & $3,821,651$ & chemotaxis protein CheYll & CC0437 & 3 & C. crescentus $C B / 5$ \\
\hline PHZ_c3376 & $3,823,068$ & $3,822,040$ & chemotaxis response regulator $\mathrm{CheB}$ & CC0436 & 3 & C. crescentus $C B / 5$ \\
\hline PHZ_c3377 & $3,823,955$ & $3,823,068$ & chemotaxis protein methyltransferase CheR & CC0435 & 3 & A. cryptum JF-5 \\
\hline PHZ_c3378 & $3,824,410$ & $3,823,946$ & chemotaxis protein $\mathrm{CheW}$ & CC0434 & 3 & Rhizobium etli CFN 42 \\
\hline PHZ_c3379 & $3,826,614$ & $3,824,422$ & chemotaxis histidine kinase CheA & CC0433 & 3 & A. cryptum JF-5 \\
\hline $\mathrm{PHZ} \_\mathrm{c} 3380$ & $3,826,997$ & $3,826,635$ & chemotaxis protein CheYl & $\mathrm{CC} 0432$ & 3 & Caulobacter vibrioides \\
\hline PHZ_c338I & $3,827,299$ & $3,826,997$ & CheX protein & CC043I & 3 & Sinorhizobium meliloti \\
\hline PHZ_c3382 & $3,829,234$ & $3,827,306$ & methyl-accepting chemotaxis protein McpA & CC0430 & 3 & A. cryptum JF-5 \\
\hline PHZ_c0IOI & 94,220 & 93,750 & CheE protein & - & scatted & C. crescentus $C B / 5$ \\
\hline $\mathrm{PHZ} \_\mathrm{c} 0102$ & 94,795 & 94,220 & chemotaxis protein CheYIII & - & scatted & C. crescentus $C B / 5$ \\
\hline $\mathrm{PHZ} \_0297$ & 292,469 & 292,864 & chemotaxis protein CheYIV & CC347I & scatted & C. crescentus $C B / 5$ \\
\hline PHZ_c0298 & 292,867 & 293,679 & chemotaxis protein methyltransferase CheR & CC3472 & scatted & C. crescentus $C B / 5$ \\
\hline $\mathrm{PHZ} \_0732$ & 803,383 & 804,876 & methyl-accepting chemotaxis protein McpB & $\mathrm{CC} 0428$ & scatted & C. crescentus $C B / 5$ \\
\hline PHZ_c096I & $1,057,134$ & $\mathrm{I}, 058,720$ & methyl-accepting chemotaxis protein Mcpl & CC2847 & scatted & R. palustris CGA009 \\
\hline $\mathrm{PHZ} \_\mathrm{cl} 198$ & $1,380,883$ & $1,383,294$ & methyl-accepting chemotaxis protein $\mathrm{McpU}$ & - & scatted & A. cryptum JF-5 \\
\hline PHZ_cll99 & $\mathrm{I}, 383,297$ & $\mathrm{I}, 383,758$ & chemotaxis protein $\mathrm{CheWI}$ & - & scatted & Sinorhizobium meliloti \\
\hline $\mathrm{PHZ}$ _cl687 & $1,890,274$ & $1,891,176$ & chemotaxis MotB protein & $\mathrm{CCI} 573$ & scatted & C. crescentus $C B / 5$ \\
\hline PHZ_cl936 & $2,169,634$ & $2,169,939$ & chemotactic signal response protein CheL & CC2583 & scatted & C. crescentus $C B / 5$ \\
\hline $\mathrm{PHZ} \_\mathrm{c} 221 \mathrm{I}$ & $2,499,744$ & $2,499,274$ & chemotaxis protein CheYIII & - & scatted & O. alexandrii HTCC2633 \\
\hline PHZ_c2392 & $2,720,611$ & $2,720,144$ & chemotaxis protein CheYIII & - & scatted & C. crescentus $C B / 5$ \\
\hline PHZ_c274I & $3,142,750$ & $3,143,238$ & chemotaxis protein CheYIII & CC3I55 & scatted & C. crescentus $C B / 5$ \\
\hline PHZ_c3123 & $3,549,150$ & $3,550,016$ & chemotaxis MotA protein & CC0750 & scatted & C. crescentus $C B / 5$ \\
\hline $\mathrm{PHZ}$ c340I & $3,848,811$ & $3,850,766$ & methyl-accepting chemotaxis protein McpA & - & scatted & C. vibrioides \\
\hline
\end{tabular}

neum can functionally compliment that of $C$. crescentus in our experimental conditions (data not shown).

Taken together, the comparative genomics of $P$. zucineum and $C$. crescentus suggests that the cell cycle of the former is likely to be regulated similarly to that of the latter.

\section{Presence of ESTs of the strain in human}

Since P. zucineum strain $\mathrm{HLK} 1^{\mathrm{T}}$ can invade and persistently live in several human cell lines [1], we were curious about whether this microbe can infect humans. By blasting against the human EST database (dbEST release 041307 with 7,974,440 human ESTs) with the whole genome sequence of $P$. zucineum, we found 9 matched ESTs (Table $14)$, of which 3 were from a library constructed from tissue adjacent to a breast cancer, and 6 were from a library constructed from a cell line of lymphatic origin. The preliminary data suggest that $P$. zucineum may invade humans.

\section{Conclusion}

This work presents the first complete bacterial genome in the genus Phenylobacterium. Genome analysis reveals the fundamental basis for this strain to invade and persistently survive in human cells. P. zucineum is phylogeneti- 
Table 8: Flagella genes in the $P$. zucineum genome

\begin{tabular}{|c|c|c|c|c|c|}
\hline Locus & 5'-end & 3'-end & Name & Gene symbol & Proposed role \\
\hline PHZ_c0080 & 75,413 & 76,462 & flagellin modification protein FImA & flmA & regulator \\
\hline PHZ_c008I & 76,467 & 77,621 & flagellin modification protein FImB & $f \operatorname{lm} B$ & regulator \\
\hline PHZ_c0745 & 816,772 & 818,034 & flagellar hook-length control protein FliK & flik & flagellar structure \\
\hline PHZ_c0787 & 868,051 & 866,696 & flagellar hook protein FlgE & flgE & flagellar structure \\
\hline PHZ_c0788 & 868,860 & 868,171 & flagellar hook assembly protein FlgD & flgD & flagellar structure \\
\hline PHZ_c0789 & 870,604 & 868,865 & flagellar hook length determination protein & flage & regulator \\
\hline PHZ_c0790 & 870,819 & 872,918 & flagellar hook-associated protein & flaN & flagellar structure \\
\hline PHZ_c079l & 872,933 & 873,862 & flagellin and related hook-associated proteins & - & flagellar structure \\
\hline PHZ_c0853 & 945,008 & 946,354 & flagellum-specific ATP synthase Flil & flil & protein export ATPase \\
\hline PHZ_c0854 & 946,354 & 946,758 & flij protein & flij & flagellar structure \\
\hline PHZ_c0857 & 950,714 & 948,621 & flagellar biosynthesis protein FlhA & fih $A$ & export apparatus \\
\hline $\mathrm{PHZ}$ _c0859 & 952,470 & 952,138 & flagellar motor switch protein FliN & fliN & motor \\
\hline PHZ_c0860 & 953,126 & 952,479 & flbE protein & $f l b E$ & regulator \\
\hline PHZ_c086I & 954,151 & 953,126 & flagellar motor switch protein FliG & fliG & motor \\
\hline PHZ_c0862 & 955,794 & 954,151 & flagellar M-ring protein FliF & fliF & flagellar structure \\
\hline PHZ_c0913 & $1,007,753$ & $1,006,992$ & flagellar L-ring protein FlgH & $\mathrm{flgH}$ & flagellar structure \\
\hline PHZ_c0914 & $1,008,508$ & $1,007,753$ & distal basal-body ring component protein FlaD & flaD & flagellar structure \\
\hline PHZ_c0915 & $1,009,300$ & $1,008,515$ & flagellar basal-body rod protein FlgG & flg $G$ & flagellar structure \\
\hline PHZ_c0916 & $1,010,052$ & $1,009,318$ & flagellar basal-body rod protein FlgF & flgF & flagellar structure \\
\hline PHZ_c0917 & $1,010,272$ & $1,010,874$ & flagellar basal body-associated protein FliL & flit & flagellar structure \\
\hline PHZ_c0918 & $1,010,910$ & $1,011,983$ & flagellar motor switch protein FliM & flim & motor \\
\hline PHZ_c0922 & $1,017,085$ & $1,016,351$ & flagellar biosynthesis protein FliP & flip & export apparatus \\
\hline PHZ_c0923 & $1,017,420$ & $1,017,151$ & flagellar protein FliO & flio & export apparatus \\
\hline PHZ_c0924 & $1,017,502$ & $1,017,918$ & flagellar basal-body rod protein FlgB & $f \lg B$ & flagellar structure \\
\hline PHZ_c0925 & $1,017,942$ & $1,018,355$ & flagellar basal-body rod protein FlgC & $f \lg C$ & flagellar structure \\
\hline PHZ_c0926 & $1,018,370$ & $1,018,678$ & flagellar hook-basal body complex protein FliE & flie & flagellar structure \\
\hline PHZ_c0930 & $1,021,796$ & $1,022,056$ & flagellar biosynthesis protein FliQ & fliQ & export apparatus \\
\hline PHZ_c093I & $1,022,079$ & $1,022,837$ & flagellar biosynthesis protein FliR & fliR & export apparatus \\
\hline PHZ_c0932 & $1,022,837$ & $1,023,913$ & flagellar biosynthesis protein FlhB & fihB & export apparatus \\
\hline $\mathrm{PHZ} \_\mathrm{cl} 380$ & $1,563,28 \mid$ & $1,562,745$ & putative flagella accessory protein $\mathrm{FlaCE}$ & flaCE & flagellar structure \\
\hline $\mathrm{PHZ}$ cl38I & $1,565,145$ & $1,563,358$ & flagellin modification protein FlmG & $f \operatorname{lm} G$ & regulator \\
\hline PHZ_cl382 & $\mathrm{I}, 565,343$ & $\mathrm{I}, 565,765$ & flagellar repressor protein FlbT & $f l b T$ & regulator \\
\hline PHZ_cl383 & $1,565,782$ & $1,566,093$ & flagellar biosynthesis regulator FlaF & flaF & regulator \\
\hline $\mathrm{PHZ}$ _cl384 & $1,566,375$ & $1,567,202$ & flagellin FljM & fljM & flagellar structure \\
\hline PHZ_cl385 & $1,567,469$ & $1,568,3 \mid 4$ & flagellin FljM & fjM & flagellar structure \\
\hline $\mathrm{PHZ}$ _cl386 & $\mathrm{I}, 568,434$ & $\mathrm{I}, 568,724$ & flagellin FlaG & flaG & flagellar structure \\
\hline $\mathrm{PHZ}$ _cl387 & I,568,887 & $1,569,720$ & flagellin FljL & fljL & flagellar structure \\
\hline PHZ_cl935 & $2,168,522$ & $2,169,634$ & flagellar P-ring protein Fgll & fgll & flagellar structure \\
\hline PHZ_cl937 & $2,169,942$ & $2,170,382$ & flagellar basal-body protein FlbY & $f l b Y$ & flagellar structure \\
\hline $\mathrm{PHZ} \_\mathrm{C} 2595$ & $2,982,550$ & $2,983,593$ & flagellin modification protein FlmD & $f \mathrm{mD}$ & regulator \\
\hline PHZ_c2597 & $2,984,874$ & $2,986,508$ & flagellin modification protein FlmG & flmG & regulator \\
\hline PHZ_c2599 & $2,989,315$ & $2,989,974$ & flmC; flagellin modification protein FlmC & $f \operatorname{lm} C$ & regulator \\
\hline PHZ_c2600 & $2,990,549$ & $2,989,977$ & flagellin modification protein FlmH & $\mathrm{flmH}$ & regulator \\
\hline
\end{tabular}

cally closest to C. crescentus based on comparative genome analysis.

\section{Methods}

\section{Bacterial growth and genomic library construction}

P. zucineum strain HLK1 $1^{\mathrm{T}}$ was grown in LB (Luria-Bertani) broth at $37^{\circ} \mathrm{C}$ and then harvested for the preparation of genomic DNA[1]. Genomic DNA was prepared using a bacterial genomic DNA purification kit (V-Gene Biotech., Hangzhou, China) according to the manufacturer's instructions. Sheared DNA samples were fractionated to construct three different genomic libraries, containing average insert sizes of $2.0-2.5 \mathrm{~kb}, 2.5-3.0 \mathrm{~kb}$ and $3.5-4.0$ $\mathrm{kb}$. The resulting pUC18-derived library plasmids were extracted using the alkaline lysis method and subjected to direct DNA sequencing with automated capillary DNA sequencers (ABI3730 or MegaBACE1000).

\section{Sequencing and finishing}

The genome of $P$. zucineum was sequenced by means of the whole genome shotgun method with the phred/ phrap/consed software packages [24-27]. Sequencing and 
Table 9: Distributions of proteins involved in environmental adaptation in P. zucineum and representative alphaproteobacteria with different living habitats

\begin{tabular}{|c|c|c|c|c|c|c|}
\hline Species & S. meliloti & B. suis & C. crescentus & P. zucineum & R. conorii & G. oxydans \\
\hline Genome size (Mb) & 6.69 & 3.32 & 4.02 & 4.38 & 1.27 & 2.92 \\
\hline GC content (\%) & 62.2 & 57.3 & 67.2 & $7 I .1$ & 32.4 & 60.8 \\
\hline Habitat & Multiple' & Facultativel & Aquatic' & Facultative $^{2}$ & Obligate' & Multiple ${ }^{3}$ \\
\hline$E C F$, extracytoplasmic function sigma factor (/Mb) & II (I.6) & $2(0.6)$ & $15(3.7)$ & $17(3.9)$ & $0(0)$ & $2(0.7)$ \\
\hline Transcriptional regulator $(/ \mathrm{Mb})$ & $433(64.7)$ & $149(44.9)$ & $183(45.5)$ & $170(38.8)$ & II (8.7) & $89(30.1)$ \\
\hline Two-component signal transduction protein (/Mb) & $113(16.9)$ & $44(13.3)$ & $111(27.6)$ & $102(23.3)$ & $7(5.5)$ & $4 I(14.1)$ \\
\hline molecular chaperone & 23 & 12 & 14 & 33 & 8 & 14 \\
\hline Flagellar protein & 41 & 37 & 42 & 43 & 10 & 40 \\
\hline Chemotaxis protein & 42 & 4 & 48 & 41 & 0 & II \\
\hline Pilus protein & 13 & 4 & 9 & 16 & 2 & 4 \\
\hline Sec-dependent secretion system & II & 11 & 11 & 11 & 11 & 12 \\
\hline Sec-independent secretion system & 4 & 4 & 4 & 4 & 3 & 4 \\
\hline Type II secretory protein & 2 & 0 & 8 & 13 & 0 & 3 \\
\hline Type IV secretory protein & 9 & 8 & 9 & 31 & 15 & 1 \\
\hline
\end{tabular}

IThe habitats of S. meliloti, B. suis, and R. conorii were indicated in a recent publication [42].

${ }^{2}$ According to our recent publication [I], P. zucineum was classified as "facultative". ${ }^{3}$ Given that G. oxydans is often isolated from sugary niches (such as flowers and fruits) and associated soil (such as garden soil and baker's soil) [43], we classified G. oxydans as "multiple".

Table I0: Type IV secretion systems in the P. zucineum genome

\begin{tabular}{|c|c|c|c|c|}
\hline \multirow[t]{2}{*}{ Locus } & \multicolumn{3}{|c|}{ Location of protein } & \multirow[t]{2}{*}{ Name } \\
\hline & Genomic element & 5 '-end & 3'-end & \\
\hline PHZ_P0007 & Plasmid & 6,786 & 7,445 & type IV secretion protein, VirBI \\
\hline PHZ_P0008 & Plasmid & 7,483 & 7,800 & type IV secretion protein, VirB2 \\
\hline PHZ_P0009 & Plasmid & 7,816 & 8,148 & type IV secretion protein, VirB3 \\
\hline $\mathrm{PHZ} \_\mathrm{P} 0010$ & Plasmid & 8,144 & 10,546 & type IV secretion protein, VirB4 \\
\hline PHZ_P00II & Plasmid & 10,546 & 11,298 & type IV secretion protein, VirB5 \\
\hline PHZ_P0012 & Plasmid & 11,553 & 12,488 & type IV secretion protein, VirB6 \\
\hline PHZ_P0013 & Plasmid & $12,8 \mid 6$ & 13,493 & type IV secretion protein, VirB8 \\
\hline PHZ_P00I4 & Plasmid & 13,493 & 14,320 & type IV secretion protein, VirB9 \\
\hline PHZ_P00I5 & Plasmid & 14,320 & 15,543 & type IV secretion protein, VirBI0 \\
\hline $\mathrm{PHZ}$ PP0016 & Plasmid & 15,543 & 16,538 & type IV secretion protein, VirBII \\
\hline PHZ_cl506 & Chromosome & $1,709,481$ & $1,709,999$ & type IV secretion protein, TraF \\
\hline PHZ_cl508 & Chromosome & I,7II,058 & $1,712,773$ & type IV secretion protein, VirD2 \\
\hline PHZ_cl509 & Chromosome & $1,712,790$ & $1,714,763$ & type IV secretion protein, VirD4 \\
\hline $\mathrm{PHZ}$ _cl512 & Chromosome & $1,716,262$ & $1,717,242$ & conjugal transfer protein, TrbB \\
\hline $\mathrm{PHZ}$ Cl5I3 & Chromosome & $1,717,242$ & $1,717,559$ & conjugal transfer protein, TrbC \\
\hline $\mathrm{PHZ}$ _cl5I4 & Chromosome & $1,717,562$ & $1,717,828$ & conjugal transfer protein, TrbD \\
\hline PHZ_cl5I5 & Chromosome & $1,717,836$ & $\mathrm{I}, 720,283$ & conjugal transfer protein, TrbE \\
\hline PHZ_cl5I6 & Chromosome & $1,720,283$ & $|, 721,0| 4$ & conjugal transfer protein, TrbJ \\
\hline PHZ_cl5I7 & Chromosome & $\mathrm{I}, 721,238$ & $1,722,398$ & conjugal transfer protein, TrbL \\
\hline $\mathrm{PHZ}$ _cl518 & Chromosome & $\mathrm{I}, 722,40 \mathrm{I}$ & $1,723,084$ & conjugal transfer protein, TrbF \\
\hline PHZ_cl519 & Chromosome & $\mathrm{I}, 723,087$ & $1,724,064$ & conjugal transfer protein, TrbG \\
\hline $\mathrm{PHZ}$ _cl520 & Chromosome & $\mathrm{I}, 724,070$ & $1,725,212$ & conjugal transfer protein, Trbl \\
\hline PHZ_c2348 & Chromosome & $2,660,517$ & $2,660,813$ & type IV secretion protein, VirB2 \\
\hline PHZ_c2349 & Chromosome & $2,660,809$ & $2,661,144$ & type IV secretion protein, VirB3 \\
\hline $\mathrm{PHZ} \_\mathrm{c} 2350$ & Chromosome & $2,661,119$ & $2,663,497$ & type IV secretion protein, VirB4 \\
\hline PHZ_c2352 & Chromosome & $2,664,374$ & $2,665,309$ & type IV secretion protein, VirB6 \\
\hline PHZ_c2353 & Chromosome & $2,665,482$ & $2,666,159$ & type IV secretion protein, VirB8 \\
\hline PHZ_c2354 & Chromosome & $2,666,159$ & $2,667,004$ & type IV secretion protein, VirB9 \\
\hline PHZ_c2355 & Chromosome & $2,667,004$ & $2,668,041$ & type IV secretion protein, VirBI0 \\
\hline $\mathrm{PHZ} \_\mathrm{c} 2356$ & Chromosome & $2,668,046$ & $2,669,035$ & type IV secretion protein, VirBII \\
\hline PHZ_c2357 & Chromosome & $2,669,091$ & $2,670,872$ & type IV secretion protein, VirD4 \\
\hline
\end{tabular}


A

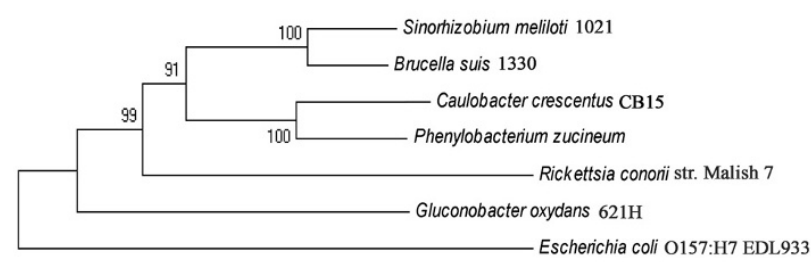

$\longmapsto 0.02$ changes

$\mathrm{C}$

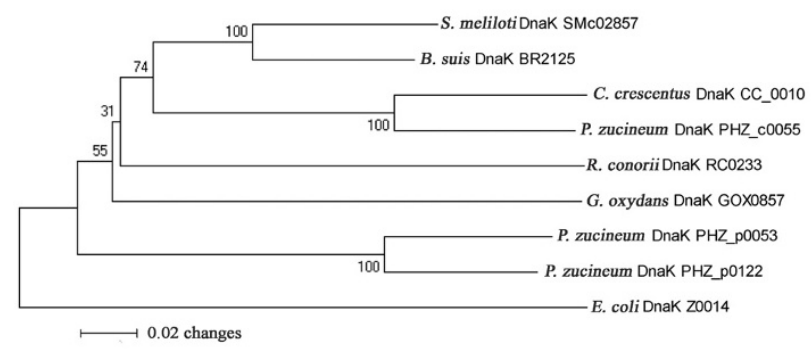

B

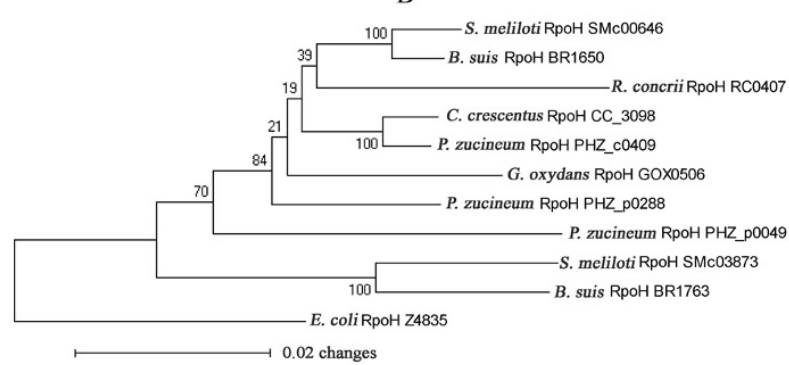

D

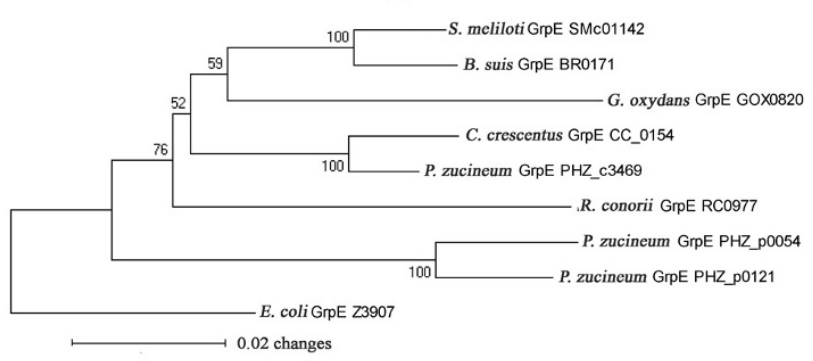

Figure 3

Neighbor-joining trees of 5 representative alphaproteobacteria and $P$. zucineum, inferred from (A) I6S rRNA genes, (B) RpoH proteins, (C) DnaK proteins and (D) GrpE proteins. The node labels are bootstrap values (I00 replicates). The plasmid-encoded DnaK and GrpE of $P$. zucineum may have undergone a genus-specific gene duplication event ( $C$ \&

subsequent gene identification was carried out as described in our earlier publications [28-30]. Briefly, during the shotgun sequence phase, clones were picked randomly from three shotgun libraries and then sequenced from both ends. 44,667 successful sequence reads ( $>100$ bp at Phred value Q13), accounting for $5.47 \times$ sequence coverage of the genome, were assembled into 563 sequence contigs representing 60 scaffolds connected by end-pairing information.
The finishing phase involved iterative cycles of laboratory work and computational analysis. To reduce the numbers of scaffolds, reads were added into initial contig assembly by using failed universal primers as primers and by using plasmid clones that extended outwards from the scaffolds as sequence reaction templates. To resolve the low-quality regions, resequencing of the involved reads in low quality regions with universal primers and primer walking the plasmid clones were the first choice, otherwise, rese-

Table I I: Pilus proteins in the $P$. zucineum genome

\begin{tabular}{|c|c|c|c|c|}
\hline Locus & 5 '-end & 3'-end & Name & Gene symbol \\
\hline PHZ_c0356 & 362,116 & 362,289 & pilus subunit protein PilA & pilA \\
\hline PHZ_c2992 & $3,4 \mid 2,800$ & $3,4|3,3| 8$ & Flp pilus assembly protein TadG & tadG \\
\hline PHZ_c2995 & $3,415,220$ & $3,415,468$ & Flp pilus assembly protein, pilin Flp & - \\
\hline PHZ_c2996 & $3,415,532$ & $3,416,023$ & Flp pilus assembly protein, protease $\mathrm{CpaA}_{\mathrm{A}}$ & cpaA \\
\hline PHZ_c2997 & $3,416,039$ & $3,416,899$ & pilus assembly protein $\mathrm{CpaB}$ & cpaB \\
\hline PHZ_c2998 & $3,416,899$ & $3,418,350$ & pilus assembly protein $\mathrm{CpaC}$ & cpaC \\
\hline PHZ_c2999 & $3,418,355$ & $3,419,587$ & pilus assembly protein $C_{p a E}$ & cpaE \\
\hline PHZ_c3000 & $3,419,594$ & $3,420,991$ & pilus assembly protein $\mathrm{CpaF}$ & cpaF \\
\hline PHZ_c300I & $3,421,030$ & $3,421,944$ & Flp pilus assembly protein TadB & $\operatorname{tadB}$ \\
\hline PHZ_c3002 & $3,421,944$ & $3,422,903$ & Flp pilus assembly protein TadC & $\operatorname{tad} C$ \\
\hline PHZ_c3027 & $3,45 I, 637$ & $3,452,566$ & Flp pilus assembly protein $C p a B$ & $c p a B$ \\
\hline $\mathrm{PHZ}$ _c3028 & $3,452,580$ & $3,453,893$ & Flp pilus assembly protein, secretin $\mathrm{CpaC}$ & $\mathrm{cpaC}$ \\
\hline $\mathrm{PHZ}$ C3029 & $3,453,893$ & $3,455,056$ & Flp pilus assembly protein, ATPase CpaE & cpaE \\
\hline PHZ_c3030 & $3,455,059$ & $3,456,489$ & Flp pilus assembly protein ATPase CpaF & $\mathrm{cpaF}$ \\
\hline PHZ_c303I & $3,456,489$ & $3,457,445$ & Flp pilus assembly protein $\mathrm{TadB}$ & $\operatorname{tad} B$ \\
\hline PHZ_c3032 & $3,457,492$ & $3,458,391$ & Flp pilus assembly protein TadC & $\operatorname{tad} C$ \\
\hline
\end{tabular}


Table 12: TonB-dependent receptors in the $P$. zucineum genome

\begin{tabular}{|c|c|c|c|}
\hline Annotation & Chromosome & Plasmid & COG category \\
\hline TonB-dependent receptor & 51 & 2 & COGI6291 \\
\hline TonB-dependent receptor vitamin $\mathrm{B} 12$ & 3 & 0 & COG $4206^{2}$ \\
\hline TonB-dependent receptor & 4 & 0 & COG $477 I^{3}$ \\
\hline
\end{tabular}

ICOG 1629, Outer membrane receptor proteins, mostly Fe transport

${ }^{2}$ COG4206, Outer membrane cobalamin receptor protein

${ }^{3}$ COG 4774, Outer membrane receptor for monomeric catechols

quencing with alternate temperature conditions resolved the remaining low-quality regions. New sequence reads obtained from the above laboratory work were assembled into existing contigs, which yielded new contigs and new scaffolds connected by end-pairing information. Then, consed interface helped us to do nest round of laboratory work based on new arisen contig assembly. After about four iterative cycles of the above "finish" procedures to close gaps and to resolve the low-quality regions, the PCR product obtained by using total genomic DNA as template was sequenced from both ends to close the last physical gap. In addition, the overall sequence quality of the genome was further improved by using the following criteria: (1) two independent high-quality reads as minimal coverage, and (2) Phred quality value $=\mathrm{Q} 40$ for each given base. Collectively, 3,542 successful reads were incorporated into initial assembles during the finishing phase. The final assembly was composed of two circular "contigs", of which a smaller one with a protein cluster (including repA, repB, parA and parB) related to plasmid replication was assigned as the plasmid, and the larger one was the chromosome.

\section{Annotation}

tRNA genes were predicted with tRNAscan-SE [31]. Repetitive sequences were detected by REPuter [32,33], coupled

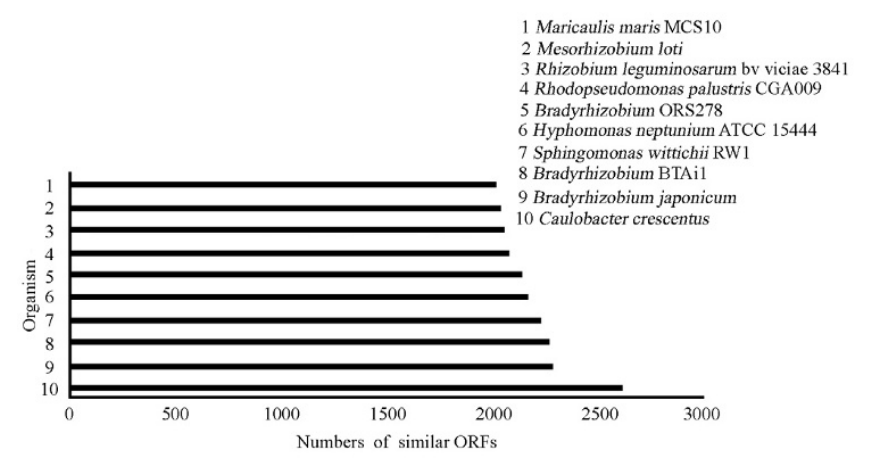

\section{Figure 4}

List of top 10 complete sequenced bacteria closest to $\boldsymbol{P}$. zucineum. All 10 are alphaproteobacteria. Among all the sequenced bacterial genomes, $C$. crescentus shares the greatest number of similar ORFs with $P$. zucineum with intensive manual alignment. We identified and annotated the protein profiles of chromosome and plasmid with the same workstream. For the chromosome, the first set of potential CDSs in the chromosome was established with Glimmer 2.0 trained with a set of ORFs longer than 500 bp from its genomic sequence at default settings [34]. The resulting 5,029 predicted CDSs were BLAST searched against the NCBI non-redundant protein database to determine their homology [35]. 1,174 annotated proteins without the word "hypothetical" or "unknown" in their function description, and without frameshifts or in-frame stop codons, were selected as the second training set. The resulting second set of 4,018 predicted CDSs (assigned as "predicted CDSs") were searched against the NCBI non-redundant protein database. Predicted CDSs that accorded with the following BLAST search criteria were considered "true proteins": (1) $80 \%$ of the query sequence was aligned and (2) E-value $\leq 1 \mathrm{e}^{-10}$. Then, the ORFs extracted from the chromosome region among "true proteins" were searched against the NCBI non-redundant protein database. The ORFs satisfying the same criteria as true proteins were considered "true ORFs". Overlapping proteins were manually inspected and resolved, according to the principle we described previously [30]. The final version of the protein profile comprised three parts: true proteins, true ORFs, and predicted CDSs located in the rest of the genome. The translational start codon of each protein was identified by the widely used RBS script [36] and then refined by comparison with homologous proteins [30].

To further investigate the function of each protein, we used InterProScan to search against the InterPro protein family database [37]. The up-to-date KEGG pathway database was used for pathway analysis [38]. All proteins were searched against the COG database which included 66 completed genomes $[39,40]$. The final annotation was manually inspected by comprehensively integrating the results from searching against the databases of $\mathrm{nr}$, $\mathrm{COG}$, KEGG, and InterPro.

\section{Phylogenetic tree construction}

16S rRNA genes were retrieved from 63 alphaproteobacteria, P. zucineum and Escherichia coli O157:H7 EDL933. A neighbor-joining tree with bootstrapping was built using 


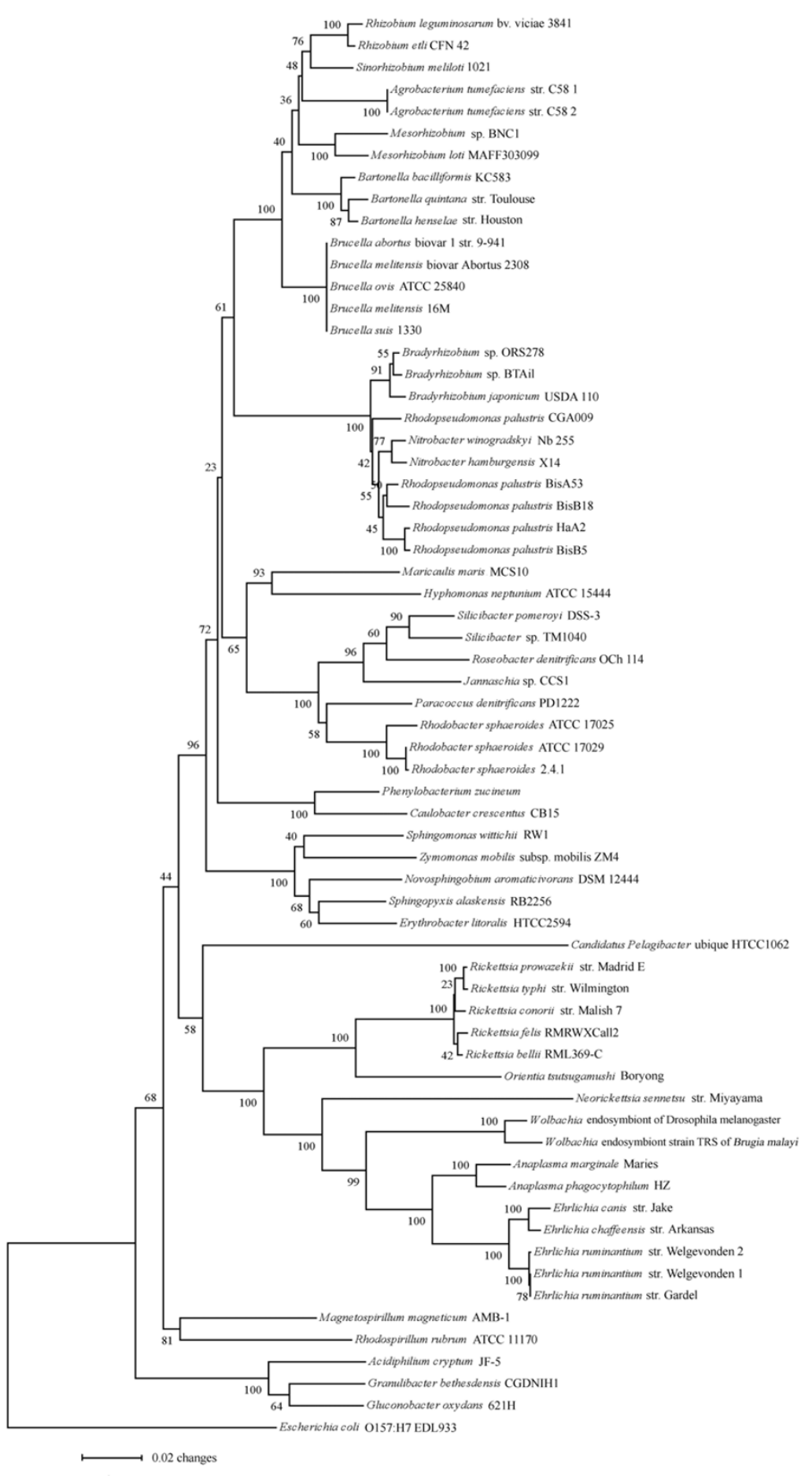

Figure 5

Neighbor-joining tree of the alphaproteobacteria, inferred from I6S rRNA genes. The node labels are bootstrap values ( 100 replicates). C. crescentus is phylogenetically the closest to P. zucineum. 
Table 13: Comparison of the signal transduction pathways regulating CtrA between the $P$. zucineum and the $C$. crescentus

\begin{tabular}{llcccc}
\hline \multirow{2}{*}{ C. crescentus } & Locus & \multicolumn{2}{c}{ Length } & Amino acid Identity (\%) & Annotation \\
& P. zucineum & C. crescentus & P. zucineum & & modification methylase CcrM \\
CC0378 & PHZ_c0577 & 355 & 359 & 80.00 & cell cycle histidine kinase CckA \\
CC1078 & PHZ_c0933 & 691 & 663 & 67.22 & sensor histidine kinase PleC \\
CC2482 & PHZ_c268I & 842 & 606 & 63.78 & sensor histidine kinase DivJ \\
CC1063 & PHZ_c27I2 & 597 & 504 & 53.83 & tyrosine kinase DivL \\
CC3484 & PHZ_c0218 & 769 & 769 & 67.66 & 89.26 \\
CC2463 & PHZ_cl309 & 130 & 121 & 80.19 & polar differentiation response regulator DivK \\
CC1963 & PHZ_cl8I7 & 202 & 205 & 90.47 & ATP-dependent protease, ClpP subunit \\
CC196I & PHZ_cl8I4 & 420 & 420 & ATP-dependent protease, ClpX subunit \\
\hline
\end{tabular}

MEGA [41]. The gammaproteobacterium E. coli was used as the outgroup to root the tree. To illustrate the evolutionary history of heat shock related proteins $(\mathrm{RpoH}$, DnaK and GrpE), neighbor-joining trees based on the $16 \mathrm{~S}$ rRNA genes and the above three proteins of 5 representative alphaproteobacteria (Sinorhizobium meliloti 1021, Brucella suis 1330, C. crescentus CB15, Rickettsia conorii str. Malish 7, Gluconobacter oxydans 621H), P. zucineum and E. coli O157:H7 EDL933 were constructed.

\section{Comparative genomics}

Sequence data for comparative analyses were obtained from the NCBI database ftp://ftp.ncbi.nlm.nih.gov/gen bank/genomes/Bacteria/. The database has 520 completely sequenced bacterial genomes (sequences downloaded on 2007/06/05). All P. zucineum ORFs were searched against the ORFs from all other bacterial genomes with BLASTP. The number of $P$. zucineum ORFs matched to each genome with significance $\left(E\right.$ value $=1 \mathrm{e}^{-}$ ${ }^{10)}$ was calculated.

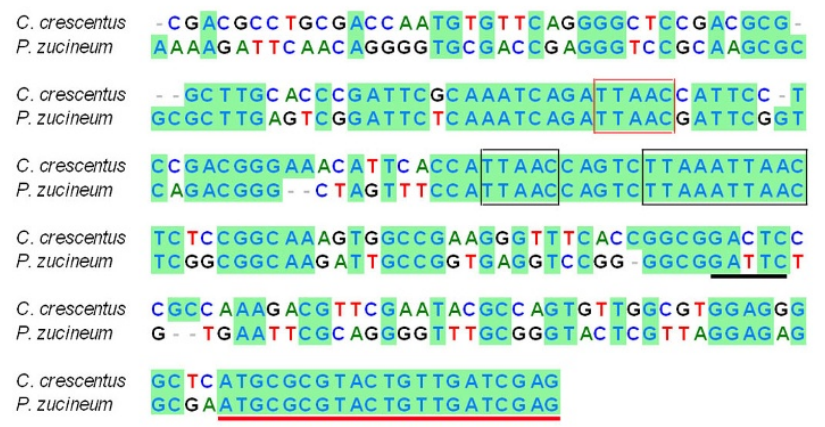

Figure 6

Nucleotide acid sequence alignment of the ctrA promoter regions $(-200$ to $+2 I)$ of $C$. crescentus and $P$. zucineum. Blue background: identical nucleotides; "-": gaps; red and black box: $\mathrm{PI}$ and $\mathrm{P} 2$ promoter; black underline: motif recognized by CcrM; red underline: first $2 \mathrm{I}$ nucleotides starting with initial codon "ATG.".
To illustrate the contribution of transcriptional regulators and two-component signal transduction proteins to environmental adaptation, we compared the mean fraction of these two types of proteins in bacteria living in 6 different habitats, as described by Merav Parter [42]. These are: (1) obligate bacteria that are necessarily associated with a host, (2) specialized bacteria that live in specific environments, such as marine thermal vents, (3) aquatic bacteria that live in fresh or seawater, (4) facultative bacteria, freeliving bacteria that are often associated with a host, (5) multiple bacteria that live in many different environments, and (6) terrestrial bacteria that live in the soil. For bacteria with more than one sequenced strain, we chose only one strain for the comparative study. The numbers of bacterial species in each group were: 26 obligate, 5 specialized, 4 aquatic, 28 facultative, 27 multiple, and 3 terrestrial. We annotated the proteins of these 93 species with the same workflow used for P. zucineum and calculated the mean fraction of transcriptional regulators and two-component signal transduction proteins.

In addition, we annotated the ORFs of 5 representative alphaproteobacteria with different habitats (multiple bacteria S. meliloti 1021 and G. oxydans $621 \mathrm{H}$, facultative bacterium B. suis 1330, aquatic bacterium C. crescentus CB15, and obligate bacterium $R$. conorii str. Malish 7) using the same workflow and computed the distributions of proteins involved in environmental adaptation.

\section{Ortholog identification}

All proteins encoded by one genome were BLASTP searched against a database of proteins encoded by another genome [35], and vice versa. The threshold used in these comparisons was $1 \mathrm{e}^{-10}$. Orthology was identified if two proteins were each other's best BLASTP hit (best reciprocal match).

\section{Data accessibility}

The sequences reported in this paper have been deposited in the GenBank database. The accession numbers for

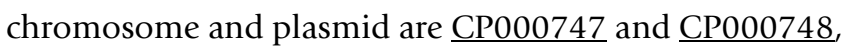
respectively. 
Table I4: Human ESTs matching the genome sequences of $P$. zucineum

\begin{tabular}{|c|c|c|c|c|c|c|c|c|c|}
\hline \multirow[t]{2}{*}{ Query GI } & \multirow[t]{2}{*}{ Sample origin } & \multirow[t]{2}{*}{ Query Length } & \multicolumn{2}{|c|}{ Query Position } & \multicolumn{2}{|c|}{ Chromosome Position } & \multirow[t]{2}{*}{ Score } & \multirow[t]{2}{*}{ E Value } & \multirow[t]{2}{*}{ Similarity (\%) } \\
\hline & & & Begin & End & Begin & End & & & \\
\hline 14251638 & Breast tissue ${ }^{1}$ & 226 & 41 & 175 & $1,276,914$ & $1,277,048$ & 204 & $2.00 \mathrm{E}-53$ & 94.07 \\
\hline $826 \mid 474$ & Breast tissue & 116 & I & 108 & I,277,042 & $1,276,937$ & 167 & $2.00 \mathrm{E}-42$ & 96.31 \\
\hline $1425 \mid 634$ & Breast tissue & 142 & 19 & 134 & $\mathrm{I}, 277,054$ & $1,276,937$ & 204 & I.00E-53 & 97.46 \\
\hline 33194938 & Lymphatic cell line $^{2}$ & 441 & 8 & 441 & $\mathrm{I}, 029,575$ & $1,029,142$ & 749 & 0 & 96.77 \\
\hline 33194696 & Lymphatic cell line & 652 & 8 & 652 & $\mathrm{I}, 029,575$ & $|, 028,93|$ & 1,166 & 0 & 97.67 \\
\hline 33193754 & Lymphatic cell line & 654 & 8 & 654 & $\mathrm{I}, 029,575$ & $1,028,929$ & 1,191 & 0 & 98.15 \\
\hline 7117824 & Lymphatic cell line & 405 & 7 & 405 & $I, 558,83 \mid$ & $1,558,433$ & 735 & 0 & 98.25 \\
\hline 33194587 & Lymphatic cell line & 638 & 7 & 638 & $2,864,470$ & $2,863,838$ & 1,191 & 0 & 98.89 \\
\hline 7114909 & Lymphatic cell line & 347 & 6 & 347 & $3,498,624$ & $3,498,283$ & 654 & 0 & 99.12 \\
\hline
\end{tabular}

'All of three sequences come from the library BN0075 containing I82 ESTs; the original dataset was produced by a modification of the EST sequencing strategy ORESTES (open reading frame expressed sequences tags)[44,45]

${ }^{2}$ All six sequences come from the library NIH_MGC_5I containing 2,38I ESTs; the original dataset was produced and released by the "Mammalian Gene Collection" project [46].

\section{Abbreviations}

EST: Expressed Sequence Tag; KEGG: Kyoto Encyclopedia of Genes and Genomes.

\section{Authors' contributions}

$\mathrm{XH}$ and $\mathrm{SH}$ designed the project; $\mathrm{YL}, \mathrm{XX}, \mathrm{ZD}, \mathrm{ZL}, \mathrm{ZY}$ and JS performed the research; $\mathrm{SH}$ and $\mathrm{BZ}$ contributed new reagents $\backslash$ analytical tools; $\mathrm{YL}, \mathrm{XX}$, and $\mathrm{ZD}$ analyzed the data; and $\mathrm{XH}, \mathrm{YL}$, and $\mathrm{SH}$ wrote the paper. All authors read and approved the final manuscript.

\section{Additional material}

\section{Additional file 1}

Supplemental Table 1 Comparison of genes directly regulated by CtrA between $\mathrm{P}$. zucineum and $\mathrm{C}$. crescentus.

Click here for file

[http://www.biomedcentral.com/content/supplementary/14712164-9-386-S1.xls]

\section{Acknowledgements}

This work was supported in part by the Cheung Kong Scholars Programme (National Ministry of Education, China, and the Li Ka Shing Foundation, Hong Kong) to $\mathrm{XH}$, a Natural Science Foundation of China grant (30672382) to $\mathrm{XH}$, and a Zhejiang Natural Science Foundation, China, grant (R204204) to XH. We thank Dr. Lucy Shapiro (Department of Developmental Biology, Stanford University) for the gifts of the $C$. crescentus temperature sensitive strain LC2195 and the plasmid PSALI4. We are grateful to Dr. lain Bruce (Department of Physiology, Zhejiang University School of Medicine) for English editing.

\section{References}

I. Zhang K, Han W, Zhang R, Xu X, Pan Q, Hu X: Phenylobacterium zucineum sp. nov., a facultative intracellular bacterium isolated from a human erythroleukemia cell line K562. Syst Appl Microbiol 2007, 30(3):207-2I2.

2. Lingens F, Blecher R, Blecher H, Blobel F, Eberspacher J, Frohner $\mathrm{C}$, Gorisch H, Gorisch H, Layh G: Phenylobacterium immobile gen. nov., sp. nov., a gram-negative bacterium that degrades the herbicide chloridazon. Int J Syst Bacteriol 1985, 35:26-39.

3. Kanso S, Patel BK: Phenylobacterium lituiforme sp. nov., a moderately thermophilic bacterium from a subsurface aquifer, and emended description of the genus Phenylobacterium. Int | Syst Evol Microbiol 2004, 54(Pt 6):2 |4|-2 | 46

4. Tiago I, Mendes V, Pires C, Morais PV, Verssimo A: Phenylobacterium falsum sp. nov., an Alphaproteobacterium isolated from a nonsaline alkaline groundwater, and emended description of the genus Phenylobacterium. Syst Appl Microbiol 2005, 28(4):295-302.

5. Aslam Z, Im WT, Ten LN, Lee ST: Phenylobacterium koreense sp. nov., isolated from South Korea. Int J Syst Evol Microbiol 2005, 55(Pt 5):200I-2005.

6. Crosson S, McGrath PT, Stephens C, McAdams HH, Shapiro L: Conserved modular design of an oxygen sensory/signaling network with species-specific output. Proc Natl Acad Sci U S A 2005, 102(22):8018-8023.

7. Arias-Barrau E, Olivera ER, Luengo JM, Fernandez C, Galan B, Garcia JL, Diaz E, Minambres B: The homogentisate pathway: a central catabolic pathway involved in the degradation of L-phenylalanine, L-tyrosine, and 3-hydroxyphenylacetate in Pseudomonas putida. J Bacteriol 2004, I 86(15):5062-5077.

8. Martinez-Bueno MA, Tobes R, Rey M, Ramos JL: Detection of multiple extracytoplasmic function (ECF) sigma factors in the genome of Pseudomonas putida KT2440 and their counterparts in Pseudomonas aeruginosa PAOI. Environ Microbiol 2003/ 0I/22 edition. 2002, 4(I 2):842-855.

9. Missiakas D, Raina S: The extracytoplasmic function sigma factors: role and regulation. Mol Microbiol 1998, 28(6): 1059-1066.

10. Pallen MJ, Chaudhuri RR, Henderson IR: Genomic analysis of secretion systems. Curr Opin Microbiol 2003, 6(5):519-527.

II. Wickner W, Schekman R: Protein translocation across biological membranes. Science 2005, 3 I0(5753):|452-|456.

12. Pizarro-Cerda J, Cossart P: Bacterial adhesion and entry into host cells. Cell 2006, I 24(4):7। 5-727.

13. Roop RM 2nd, Bellaire BH, Valderas MW, Cardelli JA: Adaptation of the Brucellae to their intracellular niche. Mol Microbiol 2004, 52(3):62। -630.

14. Miller RA, Britigan BE: Role of oxidants in microbial pathophysiology. Clin Microbiol Rev 1997, I (1): I-I8.

15. Master SS, Springer B, Sander P, Boettger EC, Deretic V, Timmins GS: Oxidative stress response genes in Mycobacterium tuberculosis: role of ahpC in resistance to peroxynitrite and stage-specific survival in macrophages. Microbiology 2002, I 48(Pt 10):3|39-3| 44 .

16. Nathan C, Shiloh MU: Reactive oxygen and nitrogen intermediates in the relationship between mammalian hosts and microbial pathogens. Proc Natl Acad Sci U S A 2000, 97( I6):884|-8848. 
17. Ratledge C, Dover LG: Iron metabolism in pathogenic bacteria. Annu Rev Microbiol 2000, 54:88I-94I.

18. Nierman WC, Feldblyum TV, Laub MT, Paulsen IT, Nelson KE, Eisen JA, Heidelberg JF, Alley MR, Ohta N, Maddock JR, Potocka I, Nelson WC, Newton A, Stephens C, Phadke ND, Ely B, DeBoy RT, Dodson RJ, Durkin AS, Gwinn ML, Haft DH, Kolonay JF, Smit J, Craven MB Khouri H, Shetty J, Berry K, Utterback T, Tran K, Wolf A, Vamathevan J, Ermolaeva M, White O, Salzberg SL, Venter JC, Shapiro L, Fraser CM: Complete genome sequence of Caulobacter crescentus. Proc Natl Acad Sci U S A 200I, 98(7):4|36-4|4|.

19. Laub MT, Chen SL, Shapiro L, McAdams HH: Genes directly controlled by CtrA, a master regulator of the Caulobacter cell cycle. Proc Natl Acad Sci U S A 2002, 99(7):4632-4637.

20. Skerker JM, Laub MT: Cell-cycle progression and the generation of asymmetry in Caulobacter crescentus. Nat Rev Microbiol 2004, 2(4):325-337.

21. Domian IJ, Reisenauer A, Shapiro L: Feedback control of a master bacterial cell-cycle regulator. Proc Natl Acad Sci U S A 1999, 96(I 2):6648-6653.

22. Reisenauer A, Kahng LS, McCollum S, Shapiro L: Bacterial DNA methylation: a cell cycle regulator? J Bacteriol 1999, I8I(I7):5I35-5I39.

23. Quon KC, Marczynski GT, Shapiro L: Cell cycle control by an essential bacterial two-component signal transduction protein. Cell 1996, 84(I):83-93.

24. Ewing B, Green P: Base-calling of automated sequencer traces using phred. II. Error probabilities. Genome Res 1998, 8(3): $186-194$.

25. Ewing B, Hillier L, Wendl MC, Green P: Base-calling of automated sequencer traces using phred. I. Accuracy assessment. Genome Res 1998, 8(3): 175-185.

26. Gordon D, Abajian C, Green P: Consed: a graphical tool for sequence finishing. Genome Res 1998, 8(3):195-202.

27. Fleischmann RD, Adams MD, White $O$, Clayton RA, Kirkness EF, Kerlavage AR, Bult CJ, Tomb JF, Dougherty BA, Merrick JM, McKenney K, Sutton G, Fitzhugh W, Fields C, Gocyne JD, Scott J, Shirley R, Liu L, Glodek A, Kelley JM, Weidman JF, Phillips CA, Spriggs T, Hedblom E, Cotton MD, Utterback TR, Hanna MC, Nguyen DT, Saudek DM, Brandon RC, Fine LD, Fritchman JL, Fuhrmann JL, Geoghagen NSM, Gnehm CL, McDonald LA, Small KV, Fraser CM, Smith HO, Venter JC: Whole-genome random sequencing and assembly of Haemophilus influenzae Rd. Science 1995, 269(5223):496-5 I2

28. Yu J, Hu S, Wang J, Wong GK, Li S, Liu B, Deng Y, Dai L, Zhou Y, Zhang $X$, Cao M, Liu J, Sun J, Tang J, Chen Y, Huang X, Lin W, Ye C, Tong W, Cong L, Geng J, Han Y, Li L, Li W, Hu G, Huang X, Li W, Li J, Liu Z, Li L, Liu J, Qi Q, Liu J, Li L, Li T, Wang X, Lu H, Wu T, Zhu $M, N i$, Han H, Dong W, Ren X, Feng X, Cui P, Li X, Wang H, Xu X, Zhai W, Xu Z, Zhang J, He S, Zhang J, Xu J, Zhang K, Zheng X, Dong J, Zeng W, Tao L, Ye J, Tan J, Ren X, Chen X, He J, Liu D, Tian W, Tian C, Xia H, Bao Q, Li G, Gao H, Cao T, Wang J, Zhao W, Li P, Chen W, Wang X, Zhang Y, Hu J, Wang J, Liu S, Yang J, Zhang G, Xiong Y, Li Z, Mao L, Zhou C, Zhu Z, Chen R, Hao B, Zheng W, Chen S, Guo W, Li G, Liu S, Tao M, Wang J, Zhu L, Yuan L, Yang H: A draft sequence of the rice genome (Oryza sativa $\mathrm{L}$. ssp. indica). Science 2002, 296(5565):79-92.

29. Chen C, Tang J, Dong W, Wang C, Feng Y, Wang J, Zheng F, Pan X Liu D, Li M, Song Y, Zhu X, Sun H, Feng T, Guo Z, Ju A, Ge J, Dong Y, Sun W, Jiang Y, Wang J, Yan J, Yang H, Wang X, Gao GF, Yang R, Wang J, Yu J: A glimpse of streptococcal toxic shock syndrome from comparative genomics of $\boldsymbol{S}$. suis 2 Chinese isolates. PLoS ONE 2007, 2(3): 315 .

30. Bao Q, Tian Y, Li W, Xu Z, Xuan Z, Hu S, Dong W, Yang J, Chen Y, Xue $Y$, Xu Y, Lai X, Huang L, Dong X, Ma Y, Ling L, Tan H, Chen R, Wang J, Yu J, Yang $\mathrm{H}$ : A complete sequence of the T. tengcongensis genome. Genome Res 2002, I 2(5):689-700.

31. Lowe TM, Eddy SR: tRNAscan-SE: a program for improved detection of transfer RNA genes in genomic sequence. Nucleic Acids Res 1997, 25(5):955-964.

32. Kurtz S, Choudhuri JV, Ohlebusch E, Schleiermacher C, Stoye J, Giegerich R: REPuter: the manifold applications of repeat analysis on a genomic scale. Nucleic Acids Res 200I, 29(22):4633-4642.

33. Kurtz S, Schleiermacher C: REPuter: fast computation of maximal repeats in complete genomes. Bioinformatics 1999, I5(5):426-427.
34. Delcher AL, Harmon D, Kasif S, White O, Salzberg SL: Improved microbial gene identification with GLIMMER. Nucleic Acids Res 1999, 27(23):4636-4641.

35. Altschul SF, Madden TL, Schaffer AA, Zhang J, Zhang Z, Miller W, Lipman DJ: Gapped BLAST and PSI-BLAST: a new generation of protein database search programs. Nucleic Acids Res 1997, 25(I 7):3389-3402.

36. Suzek BE, Ermolaeva MD, Schreiber M, Salzberg SL: A probabilistic method for identifying start codons in bacterial genomes. Bioinformatics 200 I, I7( I 2): I I23-I I30.

37. Mulder NJ, Apweiler R, Attwood TK, Bairoch A, Barrell D, Bateman A, Binns D, Biswas M, Bradley P, Bork P, Bucher P, Copley RR, Courcelle E, Das U, Durbin R, Falquet L, Fleischmann W, Griffiths-Jones S, Haft D, Harte N, Hulo N, Kahn D, Kanapin A, Krestyaninova M, Lopez R, Letunic I, Lonsdale D, Silventoinen V, Orchard SE, Pagni M, Peyruc D, Ponting CP, Selengut JD, Servant F, Sigrist CJ, Vaughan R, Zdobnov EM: The InterPro Database, 2003 brings increased coverage and new features. Nucleic Acids Res 2003, $31(1): 315-318$.

38. Kanehisa M, Goto S, Hattori M, Aoki-Kinoshita KF, Itoh M, Kawashima S, Katayama T, Araki M, Hirakawa M: From genomics to chemical genomics: new developments in KEGG. Nucleic Acids Res 2006, 34(Database issue):D354-7.

39. Tatusov RL, Koonin EV, Lipman DJ: A genomic perspective on protein families. Science 1997, 278(5338):631-637.

40. Tatusov RL, Fedorova ND, Jackson JD, Jacobs AR, Kiryutin B, Koonin EV, Krylov DM, Mazumder R, Mekhedov SL, Nikolskaya AN, Rao BS, Smirnov S, Sverdlov AV, Vasudevan S, Wolf YI, Yin J], Natale DA: The COG database: an updated version includes eukaryotes. BMC Bioinformatics 2003, 4:4I.

4I. Tamura K, Dudley J, Nei M, Kumar S: MEGA4: Molecular Evolutionary Genetics Analysis (MEGA) software version 4.0. Mol Biol Evol 2007, 24(8): 1596-1599.

42. Parter M, Kashtan N, Alon U: Environmental variability and modularity of bacterial metabolic networks. BMC Evol Biol 2007/09/25 edition. 2007, 7:169.

43. Gupta A, Singh VK, Qazi GN, Kumar A: Gluconobacter oxydans: its biotechnological applications. J Mol Microbiol Biotechnol 200I/05/ 22 edition. 200I, 3(3):445-456

44. Camargo AA, Samaia HP, Dias-Neto E, Simao DF, Migotto IA, Briones MR, Costa FF, Nagai MA, Verjovski-Almeida S, Zago MA, Andrade LE, Carrer H, El-Dorry HF, Espreafico EM, Habr-Gama A, Giannella-Neto D, Goldman GH, Gruber A, Hackel C, Kimura ET, Maciel RM, Marie SK, Martins EA, Nobrega MP, Paco-Larson ML, Pardini MI, Pereira GG, Pesquero JB, Rodrigues V, Rogatto SR, da Silva ID, Sogayar MC Sonati MF, Tajara EH, Valentini SR, Alberto FL, Amaral ME, Aneas I, Arnaldi LA, de Assis AM, Bengtson MH, Bergamo NA, Bombonato V, de Camargo ME, Canevari RA, Carraro DM, Cerutti JM, Correa ML, Correa RF, Costa MC, Curcio C, Hokama PO, Ferreira AJ, Furuzawa GK, Gushiken T, Ho PL, Kimura E, Krieger JE, Leite LC, Majumder P, Marins M, Marques ER, Melo AS, Melo MB, Mestriner CA, Miracca EC, Miranda DC, Nascimento AL, Nobrega FG, Ojopi EP, Pandolfi JR, Pessoa LG, Prevedel AC, Rahal P, Rainho CA, Reis EM, Ribeiro ML, da Ros N, de Sa RG, Sales MM, Sant'anna SC, dos Santos ML, da Silva AM, da Silva NP, Silva WA Jr., da Silveira RA, Sousa JF, Stecconi D, Tsukumo F, Valente V, Soares F, Moreira ES, Nunes DN, Correa RG, Zalcberg H, Carvalho AF, Reis LF, Brentani RR, Simpson AJ, de Souza SJ: The contribution of 700,000 ORF sequence tags to the definition of the human transcriptome. Proc Natl Acad Sci U S A 2001, 98(2I): $12103-12108$.

45. Dias Neto E, Correa RG, Verjovski-Almeida S, Briones MR, Nagai MA, da Silva W Jr., Zago MA, Bordin S, Costa FF, Goldman GH, Carvalho $A F$, Matsukuma $A$, Baia GS, Simpson DH, Brunstein $A$, de Oliveira PS, Bucher P, Jongeneel CV, O'Hare MJ, Soares F, Brentan RR, Reis LF, de Souza SJ, Simpson AJ: Shotgun sequencing of the human transcriptome with ORF expressed sequence tags. Proc Natl Acad Sci U S A 2000, 97(7):349I-3496.

46. Gerhard DS, Wagner L, Feingold EA, Shenmen CM, Grouse LH, Schuler G, Klein SL, Old S, Rasooly R, Good P, Guyer M, Peck AM, Derge JG, Lipman D, Collins FS, Jang W, Sherry S, Feolo M, Misquitta L, Lee E, Rotmistrovsky K, Greenhut SF, Schaefer CF, Buetow K, Bonner TI, Haussler D, Kent J, Kiekhaus M, Furey T, Brent M, Prange C, Schreiber K, Shapiro N, Bhat NK, Hopkins RF, Hsie F, Driscoll T, Soares MB, Casavant TL, Scheetz TE, Brown-stein MJ, Usdin TB, Toshiyuki S, Carninci P, Piao Y, Dudekula DB, Ko MS, Kawakami K, Suzuki Y, Sugano S, Gruber CE, Smith MR, Simmons B, Moore T, 
Waterman R, Johnson SL, Ruan Y, Wei CL, Mathavan S, Gunaratne PH, Wu J, Garcia AM, Hulyk SW, Fuh E, Yuan Y, Sneed A, Kowis C, Hodgson A, Muzny DM, McPherson J, Gibbs RA, Fahey J, Helton E, Ketteman M, Madan A, Rodrigues S, Sanchez A, Whiting M, Madari A, Young AC, Wetherby KD, Granite SJ, Kwong PN, Brinkley CP, Pearson RL, Bouffard GG, Blakesly RW, Green ED, Dickson MC, Rodriguez AC, Grimwood J, Schmutz J, Myers RM, Butterfield YS, Griffith M, Griffith OL, Krzywinski MI, Liao N, Morin R, Palmquist D, Petrescu AS, Skalska U, Smailus DE, Stott JM, Schnerch A, Schein JE, Jones SJ, Holt RA, Baross A, Marra MA, Clifton S, Makowski KA, Bosak S, Malek J: The status, quality, and expansion of the NIH fulllength cDNA project: the Mammalian Gene Collection (MGC). Genome Res 2004, I4(IOB):2I 2I-2I 27.

Publish with Bio Med Central and every scientist can read your work free of charge

"BioMed Central will be the most significant development for disseminating the results of biomedical research in our lifetime. "

Sir Paul Nurse, Cancer Research UK

Your research papers will be:

- available free of charge to the entire biomedical community

- peer reviewed and published immediately upon acceptance

- cited in PubMed and archived on PubMed Central

- yours - you keep the copyright

Submit your manuscript here:

http://www.biomedcentral.com/info/publishing_adv.asp
Biomedcentral 